\title{
ANÁLISE TIPOLÓGICA DAS LÁPIDES DO CEMITÉRIO NOSSA SENHORA DE LOURDES DA CIDADE DE SÃO RAIMUNDO NONATO-PI
}

Shirlene Marques de Matos*

Demétrio Mutzenberg **

Daniela Cisneiros **
RESUMO: O presente trabalho tem como objetivo principal analisar os jazigos e lápides do cemitério Nossa Senhora de Lourdes na cidade de São Raimundo Nonato - PI. Este cemitério datado do final do século XIX se encontra no perímetro urbano da cidade. A pesquisa foi desenvolvida a partir da análise de parâmetros necessários a caracterização do jazigo como nome, sexo, data de nascimento, data de falecimento, idade calculada do falecido, cronologia do jazigo, tipo de jazigo, dimensões, orientação, revestimento, a presença ou não de lápide. As lápides foram analisadas segundo critérios relacionados à sua morfologia, decoração, epitáfios, tipo de suporte e forma de inscrição. Foi possível verificar três momentos distintos na morfologia dos jazigos tomando como referência o revestimento utilizado nos mesmos e as variáveis estabelecidas para a análise.

Palavras-chave: Cemitério. Arqueologia da Morte. Tipologia. São Raimundo Nonato-PI.

ABSTRACT: This work aims analyze graves and tombstones at the Nossa Senhora de Lourdes graveyard in the city of São Raimundo Nonato - PI. This graveyard was constructed in the end of XIX century and is one of two graveyards in the urban perimeter of the city. Was analyzed all of graves and tombstones of Nossa Senhora de Lourdes graveyard to better understand how the structures behalf spatially and chronologically inside the area. The research was developed from the analysis of variables like name, sex, birth date, death date, deceased's age, grave chronology, grave type, dimensions, orientation, covering, the tombstone presence or absence. The tombstones were analyzed from canons related to morphology, decoration, epitaphs, material, and inscription method.

Key-words: Graveyard. Archaeology of Death. Typology. São Raimundo Nonato-PI. 


\section{Introdução}

Esta pesquisa ${ }^{1}$ teve como objetivo estudar a tipologia das lápides do cemitério Nossa Senhora de Lourdes, localizado no município de São Raimundo Nonato - PI. Espera-se caracterizar as lápides encontradas nesse cemitério, contextualizando-as cronologicamente e espacialmente, buscando similaridades e modificações ocorridas ao longo das décadas.

A Arqueologia desenvolve estudos ligados aos rituais funerários, em especial à dimensão material destes, com o intuito de identificar padrões culturais de grupos humanos históricos e pré-históricos (Lima, 1994; Silva, 2005; Ribeiro, 2007). Entre as pesquisas arqueológicas específicas sobre cemitérios pode-se fazer referência ao estudo da cultura material em cemitérios históricos desenvolvido nos Estados Unidos por Deetz e Dethlefsen em 1978; assim como no Brasil, por Lima (1994) e Ribeiro (2007).

Segundo Lima (1994) os jazigos constituem artefatos datáveis com precisão, já que nas lápides tumulares ficam em geral impressas datas de nascimento e falecimento dos indivíduos que ali foram enterrados. Este trabalho visou reconhecer padrões morfológicos das lápides ${ }^{2}$ e dos jazigos $^{33}$ no Cemitério Nossa Senhora de Lourdes. Foram observados elementos relativos a sua cronologia, informações contidas nos mesmos, confecção, morfologia e composição do material para a construção das estruturas.

\section{Do Povoado à Cidade}

A cidade de São Raimundo Nonato está localizada no sudeste do estado do Piauí e apresenta uma população atual de aproximadamente 30.852 habitantes, sendo 19.670 habitantes no perímetro urbano e 11.182 habitantes no perímetro rural ${ }^{4}$.

Em meados de 1832, o decreto regencial faz referência à localidade conhecida por Confusões que logo foi elevada a distrito eclesiástico com o nome de Freguesia de São Raimundo Nonato, desmembrado dos municípios de Jerumenha e Jaicós. As terras que hoje pertencem aos municípios de Caracol, Canto do Buriti e São João do Piauí faziam parte dessa freguesia (Oliveira, 2001).

Em 1836 a sede do distrito foi transferida para a localidade denominada Jenipapo, a qual, na época, era um centro populacional com ruas alinhadas, feira semanal e igreja matriz em

\footnotetext{
${ }^{1}$ Essa pesquisa resultou na monografia de conclusão de curso em Arqueologia pela Universidade Federal do Vale do São Francisco da aluna Shirlene Matos.

${ }^{2}$ Serão consideradas lápides neste trabalho, apenas as placas retangulares dispostas sobre o jazigo, que apresentarem, no mínimo, o nome do morto, a sua data de nascimento e falecimento.

${ }^{2}$ Local onde foram inumados um ou mais indivíduos, independente das condições de inumação e do tipo de edificação erigido sobre ele.

2 Dados IBGE de 2010.
} 
construção. Estava localizada em uma área de baixões e veredas às margens do rio Piauí com terras férteis onde uma pequena população desenvolveu a prática da pecuária e agricultura de subsistência (Figuras 1 e 2).

Segundo Dias (2001), com o progresso do Distrito-Freguesia, em pouco tempo este apresentou um aumento populacional, mostrando condições para reivindicar sua emancipação. Em 12 de agosto de 1850 ocorreu sua elevação à vila e em seguida, sob Lei estadual n. 669 de 25 de junho de 1912, foi elevada à categoria de cidade.

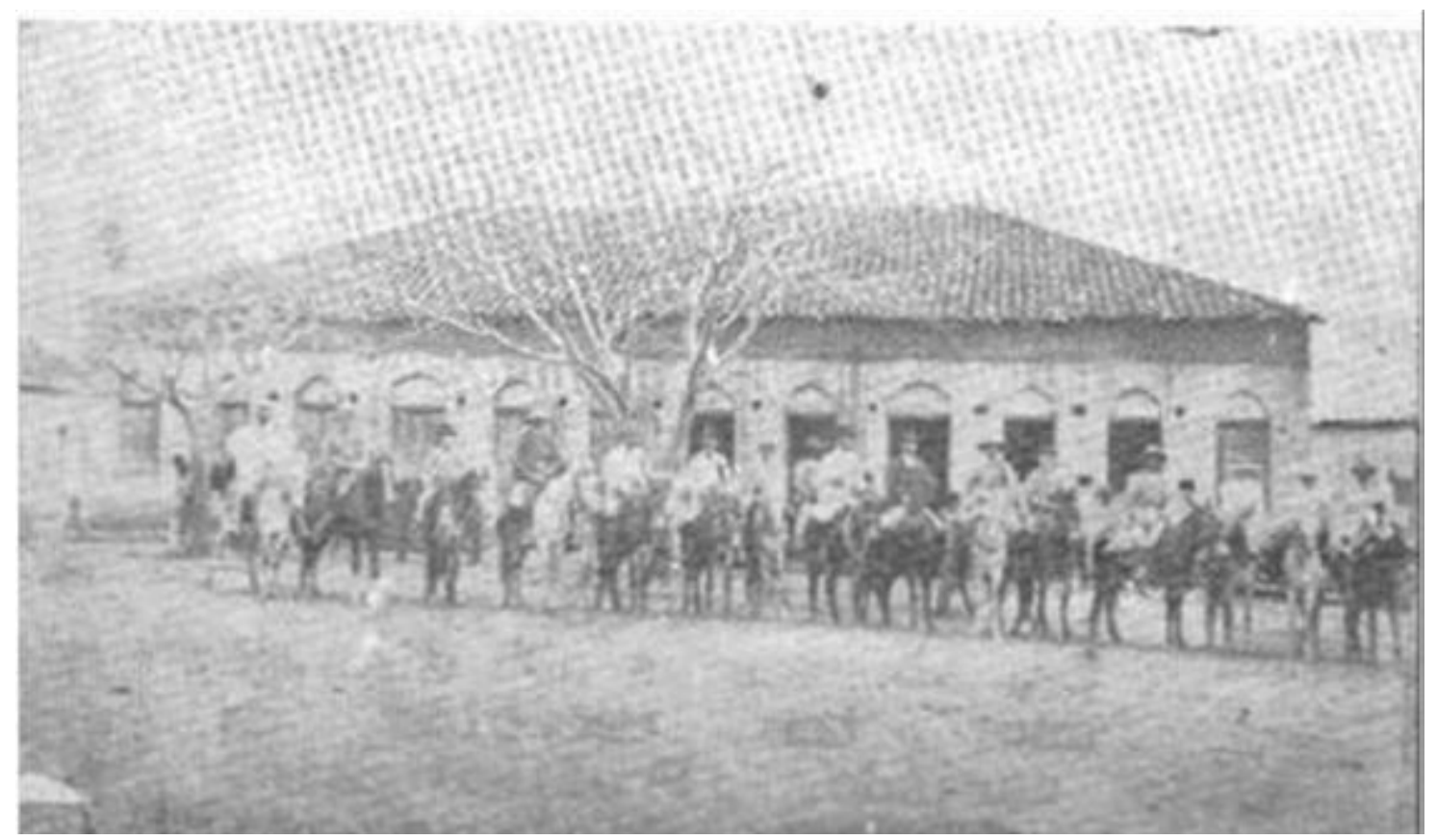

Figura 1: Provável sede da Fazenda Jenipapo. Autoria desconhecida. Fonte: Jornal Raízes do Piauí, Ano 1. Agosto de 1993.p. 7 


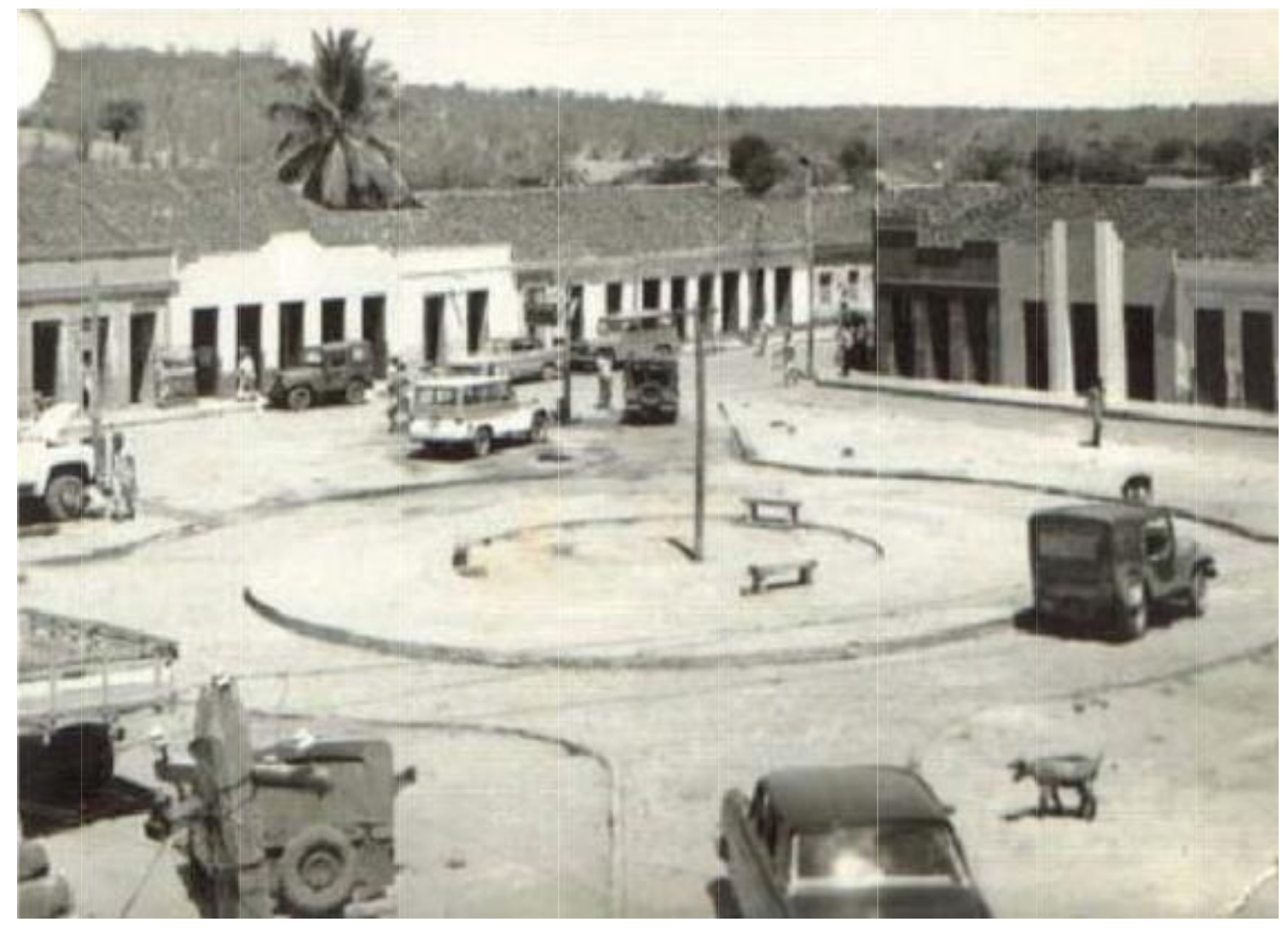

Figura 2: São Raimundo Nonato em meados do século XX, Praça Getúlio Vargas conhecida como: Rodinha do Bitoso, por volta dos anos 1940. Autoria desconhecida. Fonte: Iphan (2001).

Da construção dos Cemitérios

O hábito de realizar sepultamentos no interior das igrejas ou nos adros destas, surgiu na França em meados do século XVIII. Tal preocupação passar a existir no contexto de uma série de questionamentos sobre os hábitos higiênicos das populações, e da higienização de modo geral (Ariès apud Costa, 2007).

Nesse contexto, acreditava-se que um cemitério construído em meio a uma povoação (caso dos enterramentos das igrejas e seu entorno) acarretaria males à saúde da população que residia nas proximidades, por conta da decomposição dos cadáveres. Os mesmos transmitiriam desde doenças epidêmicas até a contaminação do ar e da água usada pela população.

No fim do século XVIII e decorrer do século XIX na Europa, ocorreu o processo de retirada dos cemitérios dos centros das povoações para outras regiões além dos limites urbanos. Na França e Portugal ocorreu a chamada "revolução dos cemitérios" (Catroga apud Flores, 2006), que constituiu na retirada dos cemitérios dos centros públicos e a construção dos cemitérios extramuros particulares. Essa profunda alteração na ocupação do espaço urbano foi idealizada e realizada por médicos, intelectuais, parlamentares e alguns eclesiásticos, envolvidos em ideais de racionalidade iluminista e liberais (Flores, 2006). 
Esse debate em torno das questões sanitárias determina a necessidade da construção de cemitérios coletivos extramuros, por se entender que os corpos, principalmente da população carente sem condições de enterrar seus mortos, que até então eram depositados nas ruas, causavam danos a saúde pública. É o início, portanto, da secularização dos cemitérios na Europa.

Nesse período surgem também os cemitérios individualizados, com caixões individuais e sepulturas reservadas para as famílias abastadas, com as devidas identificações.

No Brasil, no início do século XIX, havia uma organização espacial em relação aos enterramentos no interior das igrejas: a escolha do local de sepultura obedecia a algumas regras, como o desejo de enterros próximos entre confrades e parentes ou mesmo junto aos altares (Reis, 1991).

A construção dos cemitérios extramuros no Brasil surgiu às pressas frente a crises que se instalava durante o século XIX, ante a grande mortalidade ocasionada por epidemias que forçaram as autoridades a retirar os cemitérios dos centros urbanos. Os procedimentos com relação à instalação dos cemitérios no Brasil tinham que seguir alguns princípios fundamentais (Catroga apud Flores, 2006):

- $\quad$ ser construídos fora dos limites das povoações, em um local alto, arejado e propício à circulação dos ares e longe dos lençóis de água;

- estar resguardados por um muro;

- enterrar os corpos em covas separadas;

- a administração e a inspeção desses locais passariam às autoridades públicas, não mais ficando a cargo dos eclesiásticos.

Segundo Reis (1991) estas transformações nos cemitérios, que ocorreram em todo o ocidente cristão, acarretaram as mais diferentes reações às mudanças relacionadas às práticas dos enterramentos dentro e fora das igrejas ou próximas a povoações. Ressalta-se o caso da "Cemiterada", movimento que ocorreu em 25 de outubro de 1836. Este episódio ocorreu na Bahia em meados do século XIX e tinha como princípio a defesa de concepções religiosas sobre a morte, os mortos e os ritos fúnebres, onde se questionava a construção de cemitérios e a proibição dos enterros nas igrejas gerando um processo de separação entre os ambientes físicos dos mortos e dos vivos (Reis, 1991; Flores, 2006).

Lima (1994) define os cemitérios como espaços funerários cercados, bem delimitados, murados e gradeados. Os espaços necessitam serem cuidadosamente repartidos, quadriculados, geometricamente alinhados e ordenados, de modo a permitir a observação, a vigilância e o controle. Sua circulação deve ser bem definida e visível. Pode-se encontrar ainda em cada sepultura números, nomes e datas que individualizam os mortos, permitindo a sua imediata classificação e localização, tanto no espaço quanto na escala social, sendo todos esses dados registrados em livros sujeitos a toda sorte de inspeções, ocorrendo severas punições em casos de irregularidades. 
No sertão do nordeste do Brasil são encontrados também cemitérios que geralmente estão localizados à margem dos caminhos de muitas estradas. Em volta da primeira sepultura vão surgindo outras, com simples cruzes que normalmente designam uma lápide. Para que os animais não venham estragar o montículo de terra nem a cruz, ao redor da sepultura é colocada uma cerca de faxina (Barreto, 1940) (Figura 3).

$\mathrm{Na}$ cidade de São Raimundo Nonato foram construídos dois cemitérios murados: Nossa Senhora de Lourdes e Nossa Senhora da Piedade (Figura 4). A implantação do primeiro ocorreu no final do século XIX enquanto o segundo foi construído em meados do século XX. Ambos foram instalados sem nenhum registro do planejamento arquitetônico. Pode-se dizer que não ocorreu o processo de implantação dos cemitérios extramuros da cidade, visto que na época da construção do cemitério Nossa Senhora de Lourdes, o centro urbano da cidade estava ao redor da igreja matriz, distante apenas $700 \mathrm{~m}$ do cemitério. Enquanto que o cemitério Nossa Senhora da Piedade encontra-se incrustado no centro urbano atual da cidade de São Raimundo Nonato.

Não constam informações referentes ao impacto do processo de implantação dos cemitérios e a realização dos enterramentos nestes em detrimento das Igrejas. Inclusive ainda no ano de 1999 foi realizado o sepultamento do cônego Raimundo Álvares de Araújo no interior da Igreja.

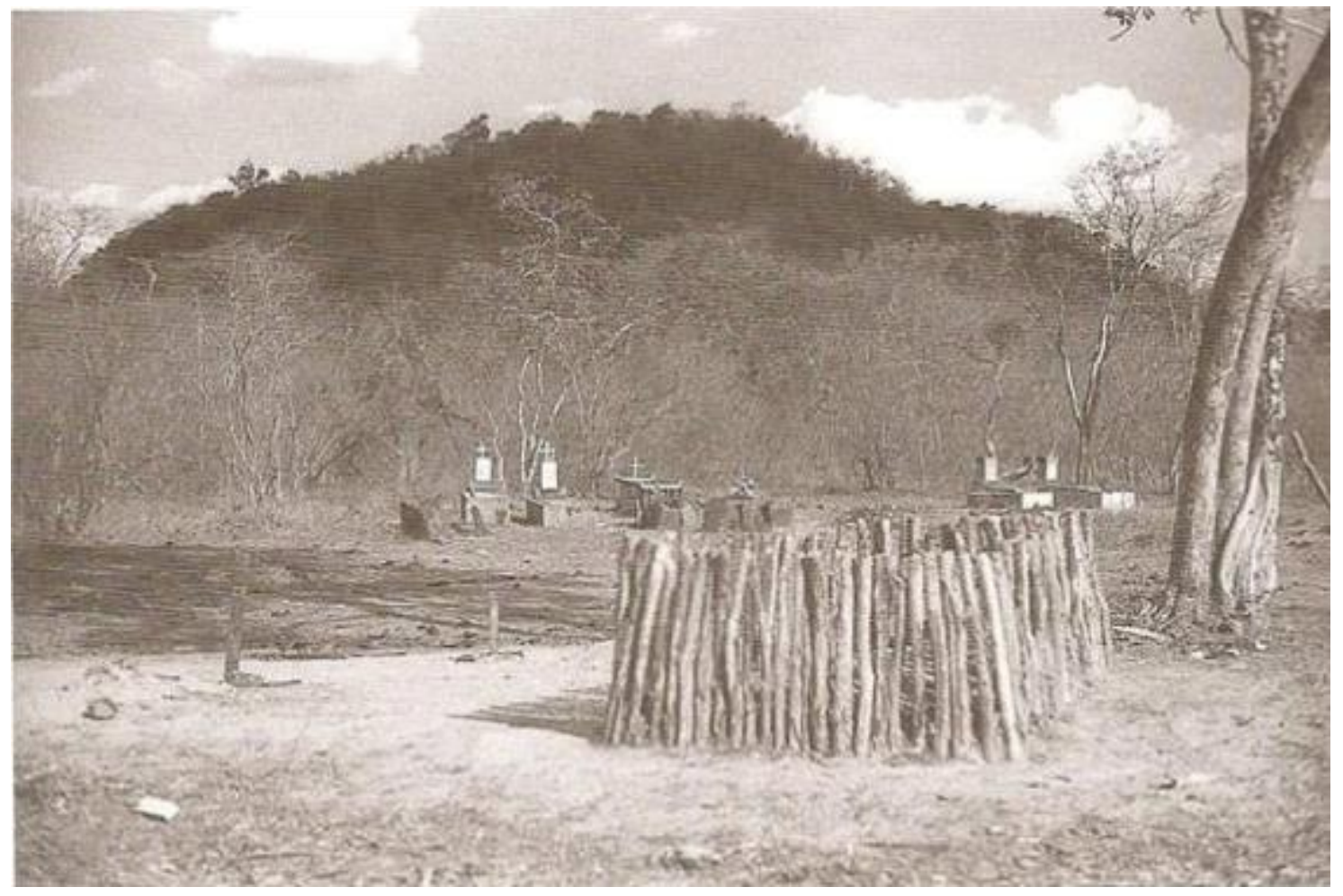

Figura 3: Sepultura com cerca de Faxina. Fonte: Silva Filho (2007). 


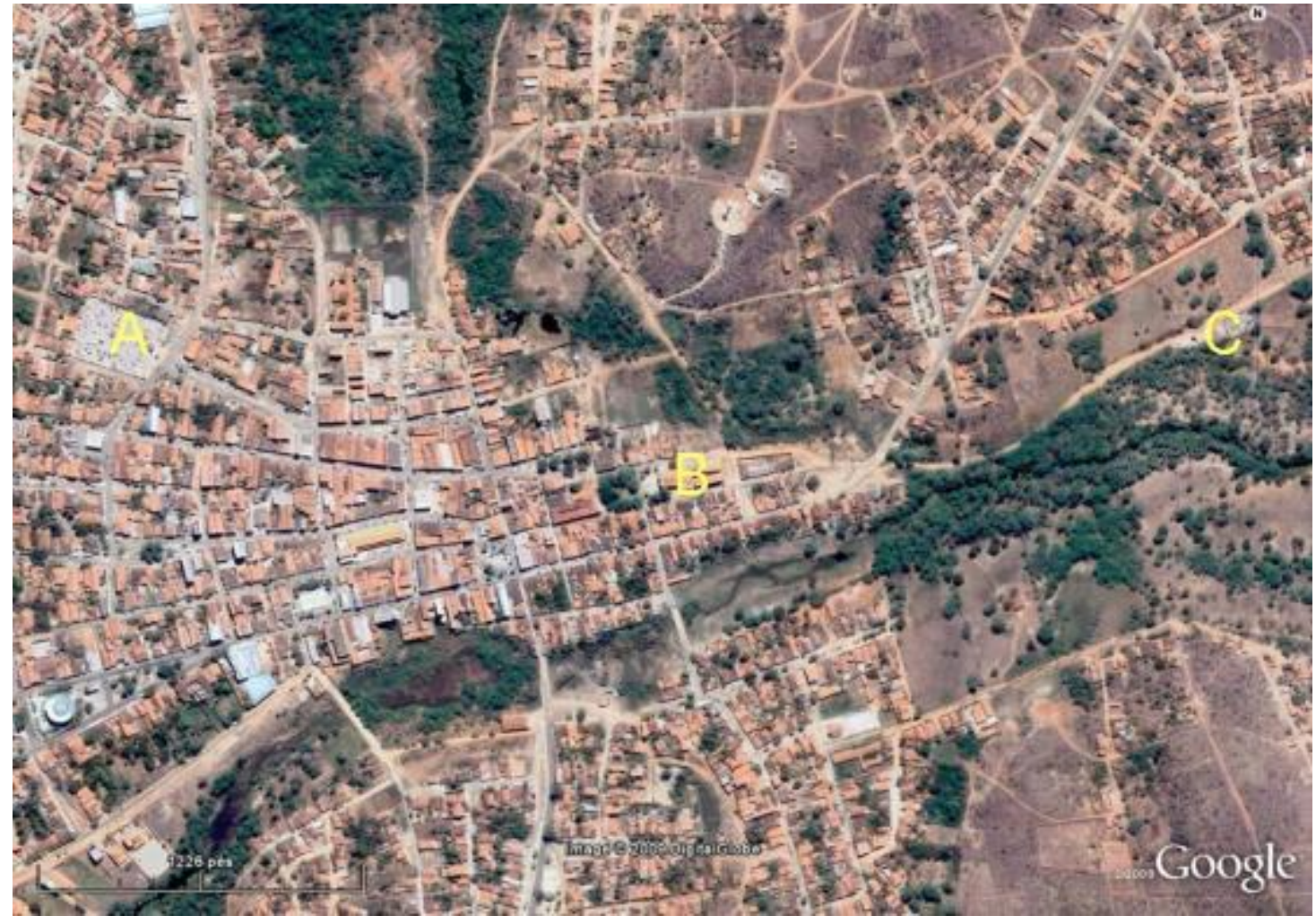

Figura 4: Mapa de Localização do Cemitério Nossa Senhora da Piedade (A); Igreja Matriz(B); e Cemitério Nossa Senhora de Lourdes(C). Fonte: Google Earth (28.08.07).

Provavelmente as famílias não pertencentes à elite local, como apontado por Penna e Neiva (1916), não sepultavam seus mortos nem em cemitérios nem nas igrejas. Algumas famílias, do interior do município de São Raimundo Nonato, tinham ainda a prática de enterrar seus mortos no quintal ou pátio das casas.

As pesquisas sobre a arquitetura funerária no Piauí são ainda insipientes, pouco numerosas e constituídas, quase sempre, de juízos de valor estético com opiniões pouco fundamentadas. Barreto (1940), por exemplo, ao analisar as estruturas funerárias do cemitério de Parnaíba afirma que este:

[...] não têm nenhum interesse ; só contém as comuns sepulturazinhas de mármore. Os demais se formaram em quadro. No centro de um dos lados, o portão de entrada e correspondendo a este, do lado oposto, pequena capela (Barreto, 1940.p.219).

Foi possível obter informações de 53 certidões de óbito referentes aos anos de 1894 a 1899 (Tabela 1). Estas certidões foram registradas no 2ำ cartório do município de São Raimundo Nonato, e disponíveis no acervo da Fundação Museu do Homem Americano (Fumdham). Esta instituição realizou um levantamento histórico na cidade de São Raimundo Nonato na década de 1980, no qual foram pesquisados documentos referentes a inventários e certidões de batismos, casamentos, nascimentos e óbitos. Todas essas informações estão acessíveis em um banco de dados nessa instituição. 
Para esta pesquisa foi selecionado como objeto de estudo o cemitério Nossa Senhora de Lourdes, inaugurado em meados do século XIX e situado no centro urbano de São Raimundo Nonato.

Tabela 1: Número de Sepultamentos obtidos dos registros de Óbitos do 2o cartório, São Raimundo Nonato, 1894-1899.

\begin{tabular}{cc}
\hline Ano & Total de Sepultamentos \\
\hline 1894 & 20 \\
1895 & 11 \\
1896 & 02 \\
1897 & 06 \\
1898 & 12 \\
1899 & 02 \\
\hline
\end{tabular}

\section{O Cemitério Nossa Senhora de Lourdes}

A implantação do cemitério Nossa Senhora de Lourdes ocorreu no ano de 1876 sendo construído praticamente nas margens do rio Piauí (Figura 5). Vale ressaltar que este é o primeiro cemitério da cidade de São Raimundo Nonato e é atualmente conhecido como Cemitério do Junco. Seu jazigo mais antigo ainda existente e data do ano de 1886 (Figura 6).

Localizado na margem esquerda do Rio Piauí, a apenas 100 m do talvegue, o cemitério Nossa Senhora de Lourdes está sujeito a inundações. Possui ainda, um aspecto diferente do modelo tradicional de cemitérios urbanos, por se encontrar em um local isolado, pouco habitado e cercado pela caatinga. $O$ acesso ao cemitério é realizado pela Avenida Prof. João Meneses, seguido por um trecho de $430 \mathrm{~m}$ sem asfalto. A distância da Igreja Matriz até o Cemitério Nossa Senhora de Lourdes é de cerca de $700 \mathrm{~m}$.

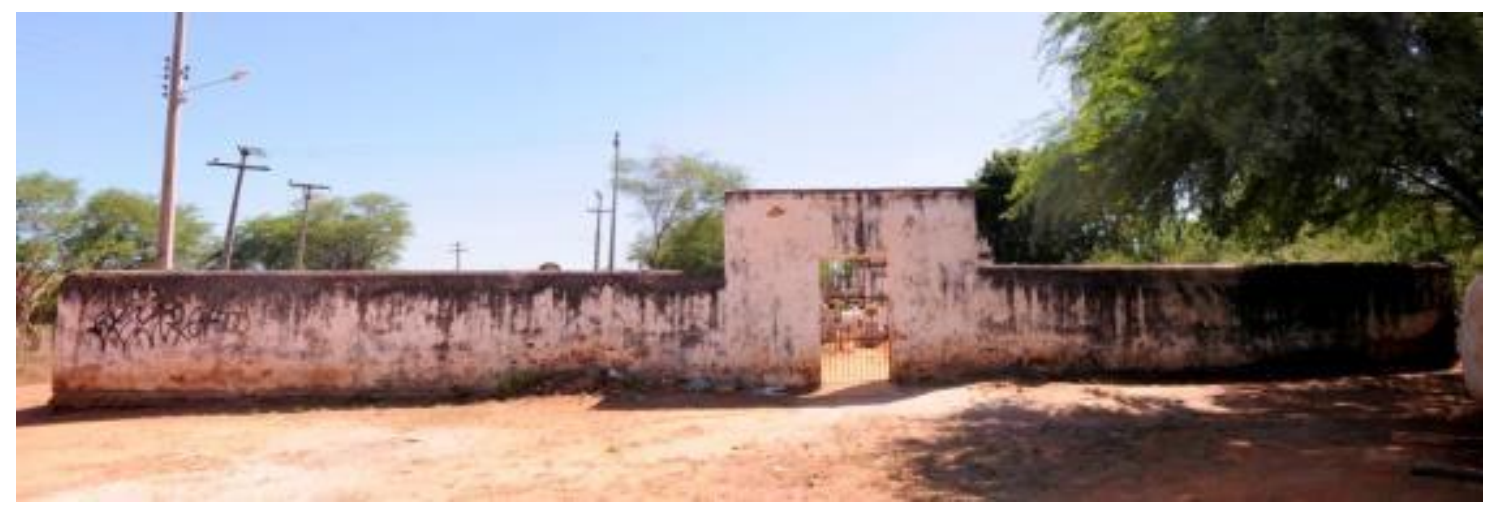

Figura 5: Fachada do Cemitério Nossa Senhora de Lourdes.

O cemitério Nossa Senhora de Lourdes possui um espaço geográfico muito pequeno, com uma área de $770 \mathrm{~m}^{2}$ originalmente dividida em quadras. Apresenta apenas uma entrada, localizada a oeste. Não existe capela pra a realização de missas ou orações, como acontece no Cemitério Nossa Senhora da Piedade. Os poucos mausoléus existentes estão localizados predominantemente no setor leste do cemitério, ou seja, distantes da entrada. As cabeceiras 
dos jazigos encontram-se geralmente orientadas para poente, embora existam exceções. Predominam as construções tumulares porém identificam-se também mausoléus e covas rasas.

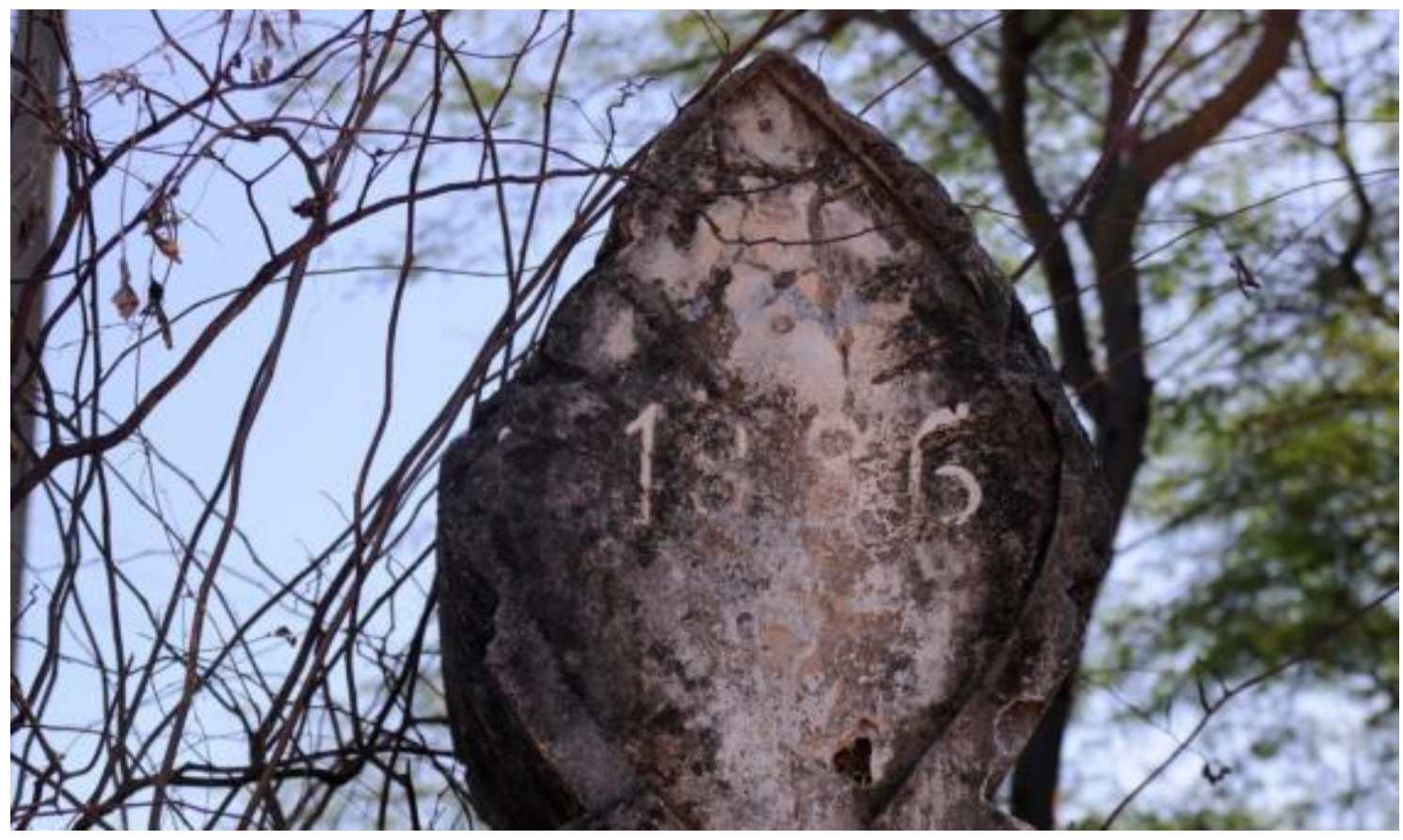

Figura 6: Inscrição do ano 1886, correspondendo ao jazigo mais antigo do Cemitério Nossa Senhora de Lourdes.

\section{Abordagem Teórica}

Ao abordar as pesquisas arqueológicas no Brasil acerca das práticas funerárias, verifica-se que as correntes teóricas como metodológicas em torno desta temática se desenvolveram de forma relativamente lenta. Estes estudos vêm sendo realizados principalmente no âmbito das Ciências Sociais e, em especial, da Antropologia. No entanto, atualmente, os trabalhos monográficos, dissertações e teses sobre esse tema têm se multiplicado de forma considerável. Lima (1994) defende que a arqueologia, pela sua ligação direta com a cultura material qualifica-se notavelmente para este tipo de investigação, sendo capaz de somar novos conhecimentos aos já produzidos a partir dos registros documentais.

Estudos da Arqueologia Histórica americana e inglesa nas pesquisas em cemitérios históricos fazem referências à utilização da cultura material através da análise das lápides e dos monumentos funerários expostos nos cemitérios (Deetz e Dethlefsen, 1971; Meyer,1971 apud Ribeiro, 2007). Através dos rituais funerários, existe uma reação social contra a destruição dos laços de solidariedade que unem o indivíduo ao grupo. A morte desequilibra a organização social, mas não aniquila a personalidade social do morto, apenas a transforma (Ribeiro, 2007). Os sepultamentos só podem ser compreendidos através das relações contextuais com outros grupos e rituais não-funerários contemporâneos. Esses sepultamentos são associações de usos 
contemporâneos, onde são inseridos tanto os rituais quanto as várias partes que compõe o equipamento funerário (Pearson apud Cisneiros, 2003 e Silva, 2005).

Os estudos que envolvem as práticas mortuárias na arqueologia são caracterizados por incluir desde os comportamentos mortuários, os acompanhamentos funerários, a distribuição espacial do cemitério, a mortalidade, as patologias e as anomalias, além de indicadores de saúde (Silva, 2005). Estes são alguns dos fatores que induzem a formação de uma conjuntura de dados arqueológicos que tem como principal objeto de estudo a sepultura.

As práticas mortuárias para Bement (1994 apud Silva, 2005) levam em consideração as variáveis biológicas, como idade, sexo e os traços herdados, além de variáveis culturais. Logo, as variáveis culturais e biológicas determinam padrões de sepultamento de uma determinada sociedade inserida numa escala de tempo de longa duração.

Segundo Cisneiros (2003), a cultura material pode ser indicativa de status, o que possibilita a reconstrução de uma estrutura social na qual se identificam as diferenças nos diferentes tipos de enterramentos, seguida da deposição do morto e composição da cova além dos objetos a estes associados, que passam a ser vistos como meio para uma identidade social. Do mesmo modo, os padrões construtivos encontrados nos jazigos foram adotados nesse estudo e analisados com a finalidade de buscar uma significação e classificação dos objetos funerários em tipos com o objetivo de identificar e analisar as mudanças ocorridas nas práticas funerárias em São Raimundo Nonato.

Segundo Funari (2003) o estudo tipológico de lápides funerárias auxilia na compreensão da sociedade que construiu e utilizou determinado cemitério, através das diferenças de suas classes e status assim como as transformações sociais no decorrer do tempo.

No estudo da tipologia das lápides no cemitério Nossa Senhora de Lourdes em São Raimundo Nonato procurou-se tratar cada jazigo como uma estrutura arqueológica, voltada para o estudo das seqüências tipológicas das mesmas.

Esta pesquisa procura identificar, através do estudo tipológico das lápides prováveis mudanças sobre o modo de ritualizar a morte no cemitério Nossa Senhora de Lourdes de São Raimundo Nonato. Essas mudanças podem envolver diferenças sociais, políticas ou religiosas na busca de uma identidade coletiva. No entanto, neste trabalho não será aprofundar informações específicas sobre o tratamento que envolve os corpos, nem o mobiliário funerário, ou os dados que estes apresentam, e sim com os dados presentes nas lápides onde é possível obter informações necessárias para este estudo; portanto, observar-se-ão os ritos funerários aplicados à sociedade contemporânea.

\section{Rituais Funerários}

Alguns dos costumes das sociedades são conduzidos nos ritos mortuários, esses costumes podem ser observados através da materialidade na prática mortuária. Nas sociedades, a representação do poder simbólico marca a transição entre vida e morte, o que faz com que os 
humanos, durante o processo da morte, procurem reafirmar suas heranças e posições sociais (Barrett apud Silva, 2005).

É possível observar alguns comportamentos em relação aos rituais da morte, ligados a nossa sociedade, enraizadas pela forte presença do catolicismo. Outro costume ritual dos sanraimundenses, e que ainda persiste em algumas cidades do interior do Piauí é a prática de compartilhar a mesa do café com parentes e amigos durante o velório. Essa é uma prática culturalmente presente na população.

Sobre os rituais fúnebres da cidade de São Raimundo Nonato, observa-se as seguintes manifestações:

- O toque dos sinos (o aviso do falecimento);

- O anúncio da morte chega através do carro de som ou rádio convidando toda a população para o velório. (essa prática é muito comum em todas as cidades do Piauí, ocorrendo também em algumas cidades do interior do nordeste);

- O velório normalmente é realizado no meio da sala (a maioria das cidades do interior do Piauí ainda se faz o velório nas residências do morto ou dos parentes), acompanhado da missa de corpo presente;

- O cortejo fúnebre segue pelas ruas da cidade (a frente do cortejo quatro pessoas, normalmente segurando o caixão, em alguns casos o caixão é levado dentro do carro da funerária, atrás dele vem acompanhando o padre e seus familiares que vão rezando o terço durante todo percurso do cortejo nas principais ruas da cidade até chegarem ao cemitério. Chama a atenção um dado que ocorre com grande freqüência, quando o cortejo passa em frente as lojas comerciais da cidade, é comum os donos de lojas fecharem suas portas em respeito à família do morto, atividade esta ainda hoje preservada, sendo uma prática utilizada desde que se passou a enterrar os mortos nos cemitérios da cidade;

- A visita de cova e missa de $7^{\circ}$ dia (no primeiro dia do enterro até o $7^{\circ}$ é rezado um terço pela alma do falecido na casa dos familiares);

- O luto na cidade de São Raimundo Nonato vem se perdendo ao longo dos tempos, embora uma minoria da população, principalmente as que moram nos povoados, são as que mais realizam e adotam certas práticas de uso de vestimentas, como a utilização de peças de tons neutros ou utilizam um pedacinho de pano preto na camisa o que simboliza o luto;

- O último ato é a missa de mês de falecimento.

\section{Método}

As práticas mortuárias na cidade de São Raimundo Nonato foram analisadas de acordo principalmente com os estudos tipológicos do Cemitério Nossa Senhora de Lourdes, 
contribuindo para o entendimento dos modelos interpretativos das estruturas tumulares no âmbito da pesquisa em arqueologia histórica.

O método utilizado partiu dos seguintes procedimentos:

- Contextualização histórica da cidade de São Raimundo do final do século XIX ao início do século XXI;

- Busca por dados dos cemitérios da cidade, em documentos ou mediante entrevistas;

- Mapeamento do Cemitério Nossa Senhora de Lourdes, apresentando suas dimensões e a localização dos jazigos;

- Posicionamento dos jazigos dentro do espaço funerário a partir da utilização do GPS Topográfico Trimble GeoXT;

- Criação de um banco de dados para todos os jazigos do Cemitério Nossa Senhora de Lourdes, contendo dados acerca do no do jazigo, nome do falecido, sexo do falecido, data de nascimento, data de falecimento, idade calculada do falecido a partir das datas de nascimento e falecimento, década do jazigo, tipo de jazigo, largura, comprimento, altura, orientação, revestimento, lápide, tipo de jazigo;

- Criação de um banco de dados para todas as lápides do Cemitério Nossa Senhora de Lourdes, contendo dados acerca da sua morfologia, decoração, epitáfios, tipo de suporte e forma de inscrição na lápide;

- Verificação das estruturas que compõem os rituais funerários encontrados na cidade de São Raimundo Nonato. Esse questionário foi elaborado para uma melhor ordenação das entrevistas, observando o comportamento da população, durante e após o ritual fúnebre;

- Identificação e classificação dos símbolos iconográficos de acordo com a freqüência em que aparecem nos jazigos e nas lápides.

- Elaboração de um registro fotográfico tanto do espaço funerário como dos jazigos e lápides estudados;

- Elaboração de uma planilha, com as informações encontradas no Cartório do $2^{\circ}$ Ofício da cidade de São Raimundo Nonato, onde se encontram certidões de óbito, de pessoas falecidas no período desde o ano de 1894 até final do século XIX (1899).

- Relacionamento entre os diversos dados coletados na pesquisa para caracterizar a disposição dos jazigos espacialmente e cronologicamente no contexto do Cemitério Nossa Senhora de Lourdes.

Em referência aos aspectos mencionados nesse estudo entende-se que o espaço funerário encontra-se bem delimitado, tanto que para esse estudo utilizou-se a seguinte divisão, na qual se propõe a partir da análise dos padrões construtivos, uma ampla descrição das lápides, 
priorizando o tipo de morfologia encontrada nos jazigos além dos símbolos iconográficos associados a sua cultura material.

O procedimento adotado partiu da disposição das sepulturas dentro do espaço funerário. Em seguida, classificou-se os diferentes tipos de jazigos ou sepulturas encontrados. Foram reconhecidas três categorias de jazigos ou sepulturas: mausoléus, túmulos e covas rasas.

Entende-se por mausoléus a categoria de estrutura que comporta sepultamentos primários ou secundários, estes podem vir em caixões ou urnas, sendo de vários indivíduos, pertencentes a uma mesma família, grupo, organização ou entidade civil e religiosa. Considerando o trabalho de Lima (1994) a mesma descreve os mausoléus a partir da forma. Trata-se de uma edificação de grande porte, de caráter monumental, muitas vezes suntuosa, alguns deles reproduzem uma pequena igreja. Por túmulos a autora conceitua como o jazigo onde foram realizados um ou mais sepultamentos primários, local onde foram dispostos os corpos articulados de um ou mais indivíduos, em posição distendida, normalmente, em caixões.

Uma vez feita à classificação e definida os tipos de jazigos, foram realizados os levantamento dos padrões construtivos e das iconografias encontradas nas sepulturas, seguindo as categorias referidas acima. Algumas destas sepulturas não apresentaram nenhuma referência cronológica o que dificultou sua identificação, portanto, os dados que não constavam no jazigo ou lápide não foram inseridos na pesquisa.

Serão analisados ainda o tamanho, estado de conservação e a situação do local onde se encontra cada jazigo. Para isso, foi desenvolvido um protocolo de pesquisa para resguardar todas essas informações encontradas nas sepulturas, o que facilitou a análise do material construtivo e em seguida todas as informações coletadas foram inseridas no banco de dados.

O cemitério Nossa Senhora de Lourdes está localizado no município de São Raimundo Nonato na região do sudeste do Piauí, na Av. Profo João Meneses, situado nas coordenadas UTM $0754971 \mathrm{E}, 9002990 \mathrm{~N}$, Fuso 23 , altitude $332 \mathrm{~m}$, com orientação leste, possuindo uma área de $770 \mathrm{~m}^{2}$.

O Cemitério apresenta atualmente 146 jazigos, estruturas funerárias que foram classificadas em termos morfológicos em três categorias: mausoléu, túmulo e cova rasa (Figuras 7A, B e C). A distribuição dos jazigos se dá da seguinte forma: 12 mausoléus; 49 covas rasas; 85 túmulos.

Todos os jazigos encontrados foram georreferenciados, podendo ser visualizados no mapa do cemitério (Figura 8). É possível perceber uma concentração de mausoléus a leste do cemitério, ou seja, na área mais distante de sua entrada (Figura 9). Os túmulos estão distribuídos de forma praticamente homogênea por todo o cemitério e as covas rasas estão localizadas, geralmente nos espaços entre os túmulos. 


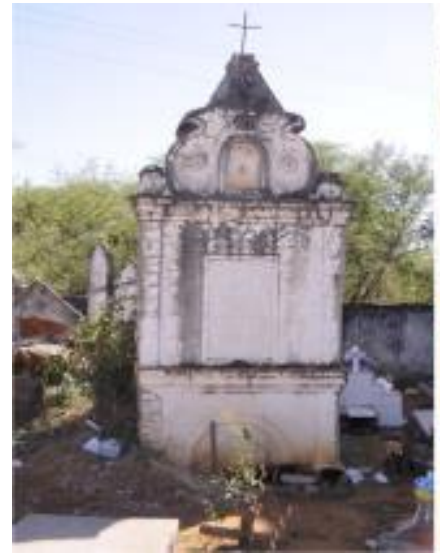

A

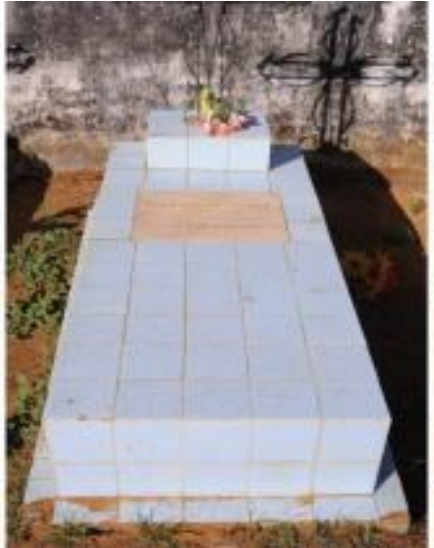

B

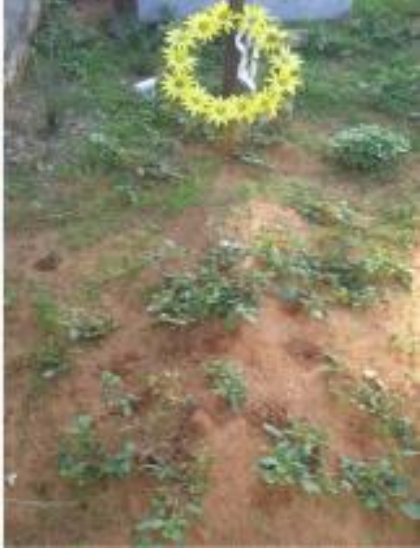

C

Figura 7: A. Mausoléu. B. Túmulo. C. Cova rasa.

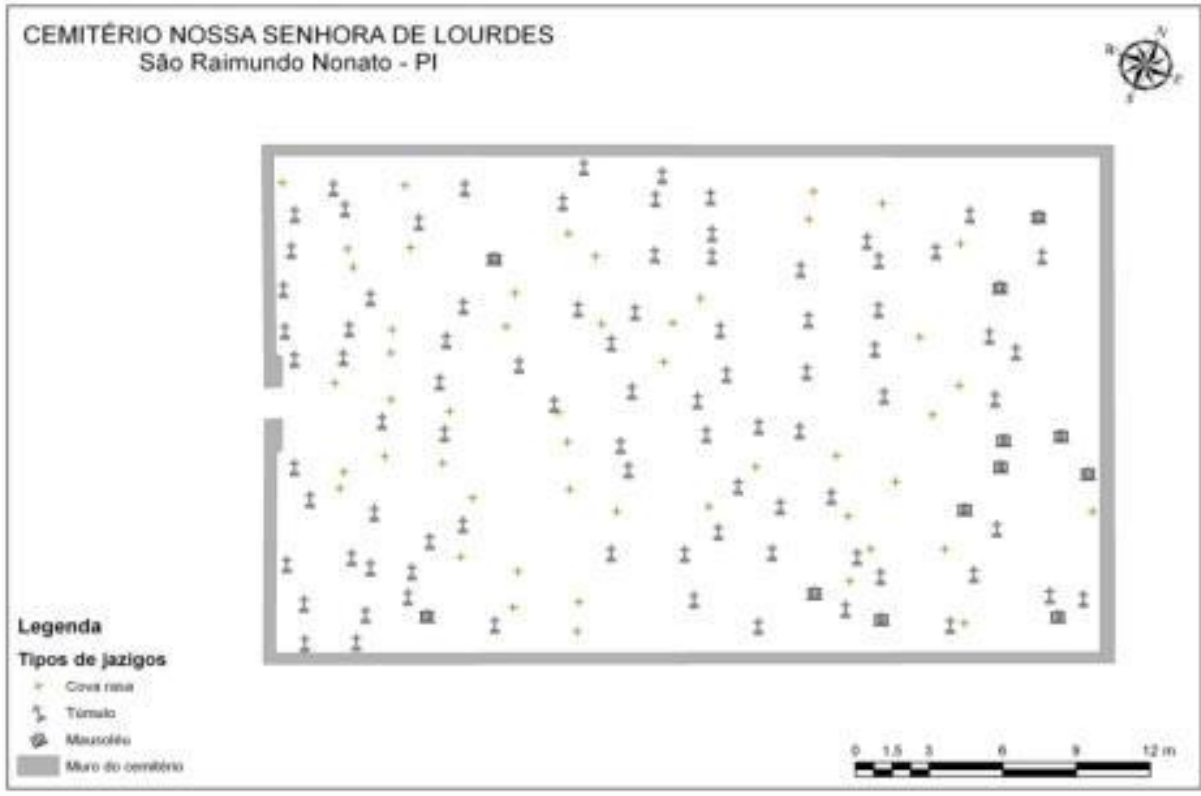

Figura 8: Distribuição dos tipos de jazigos encontrados no Cemitério Nossa Senhora de Lourdes - São Raimundo Nonato - PI. 


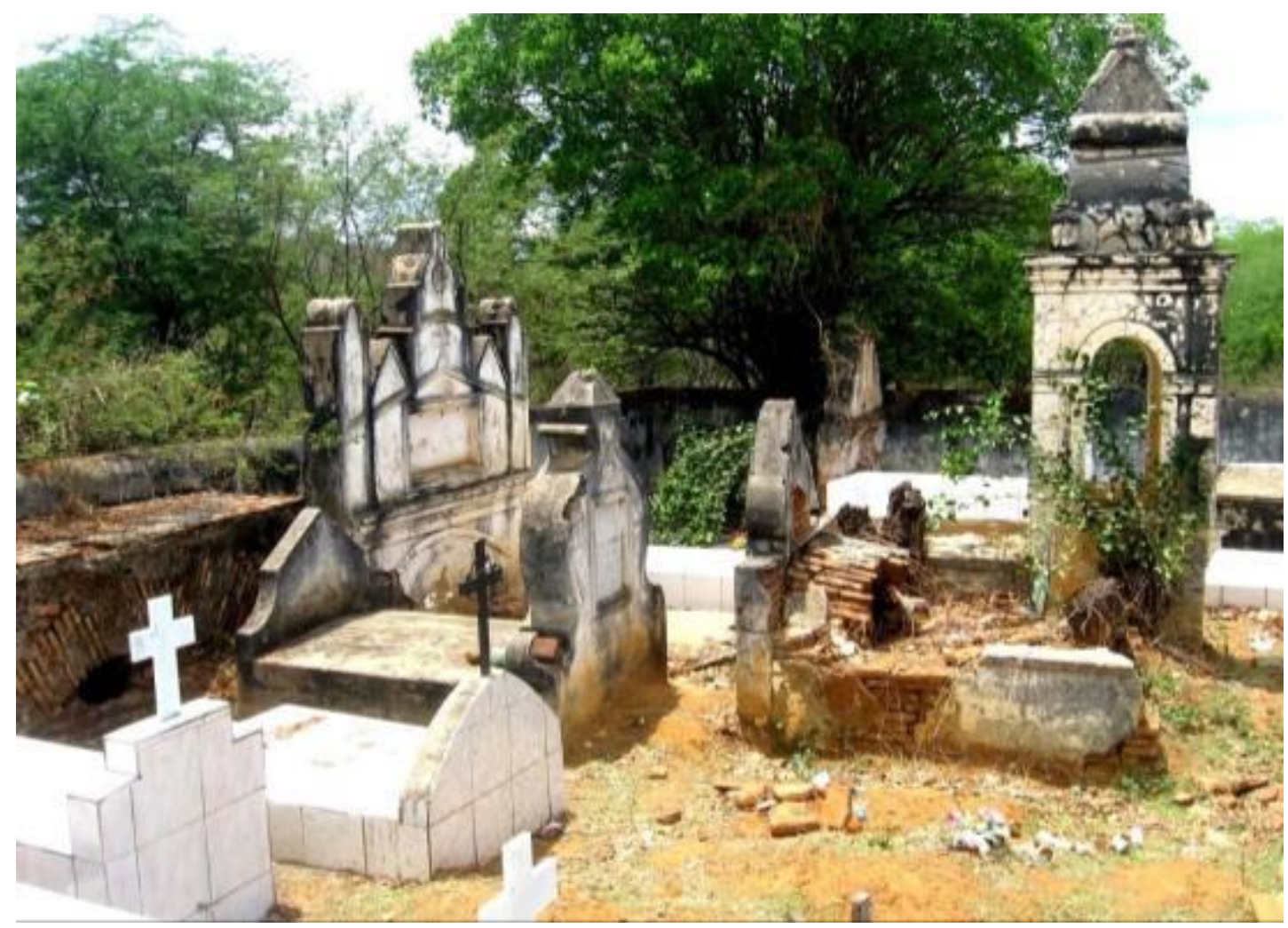

Figura 9: Concentração dos mausoléus ao leste do Cemitério Nossa Senhora de Lourdes.

Os jazigos no cemitério Nossa Senhora de Lourdes (Figuras 10 e 11) não estão totalmente alinhados devido a construções desordenadas de sepulturas mais recentes. A circulação é prejudicada pela superlotação, tornando-se difícil a locomoção dentro do cemitério.

Muito desses jazigos são postos de forma aleatória sem nenhuma inspeção por parte do município o que dificulta o controle dos sepultamentos. Vale ressaltar que o cemitério foi instalado em uma área plana, possuindo um único acesso sendo o mesmo para entrada e saída. O cemitério possui uma área que deveria ser dividida em quadras. Atualmente, não possui o mesmo espaço de anos atrás pelas condições que hoje se encontra o local. Pode-se mencionar que mesmo abandonado pelo poder público, a população local, que tem seus entes queridos ali sepultados, procura manter a área próxima aos túmulos limpa. Devido a essa situação atual de abandono ocorrem novos sepultamentos de forma desordenada que vêm causando uma maior concentração de jazigos uns sobrepostos aos outros, dificultando o acesso no seu interior.

Na maioria dos cemitérios há uma tendência em sepultar seus mortos seguindo algum tipo de orientação, normalmente utilizando os pontos cardeais. É conduzida a posição de um sepultamento, direcionando o corpo para determinar a posição exata na qual devem ficar direcionados a cabeça e os pés do morto. Pode-se inferir, partindo da argumentação do pároco Cláudio, que segundo a doutrina cristã procura-se enterrar os mortos com a cabeça voltada para o nascente - leste, a cruz normalmente deve vir em cima da cabeceira do jazigo. Nesse sentindo, o rosto deveria estar voltado para o sol, os primeiros cristãos acreditavam que o morto ressuscitaria em plena luz. Por isso sepultavam os mortos voltados para o sol. Esse 
costume é bastante presente em boa parte do Brasil. Em São Raimundo Nonato esse costume é preservado até os dias de hoje, não sendo diferente dos outros centros urbanos.

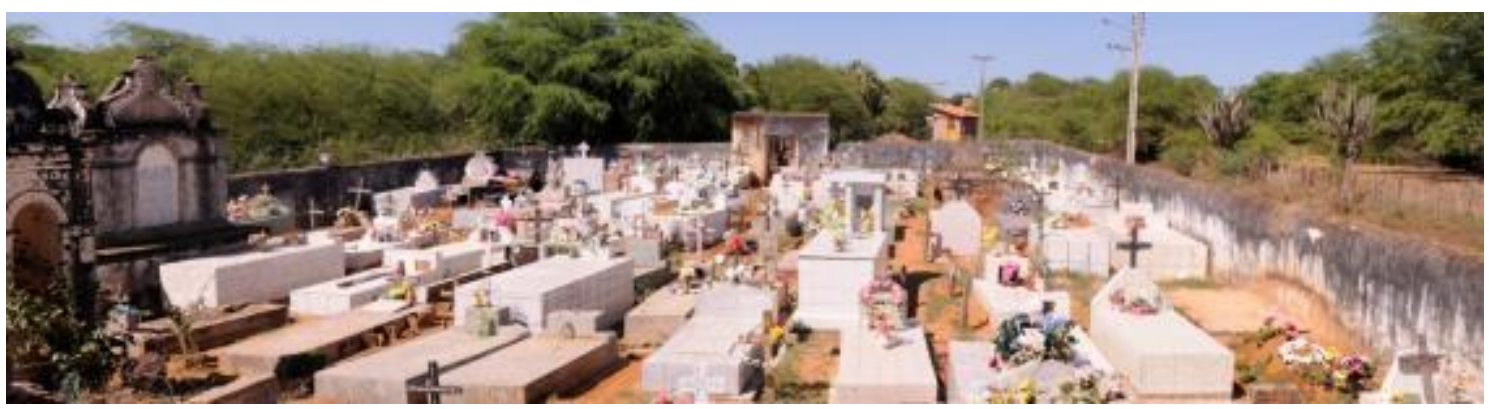

Figura 10: Vista geral do interior do Cemitério Nossa Senhora de Lourdes. Vista em direção a oeste.

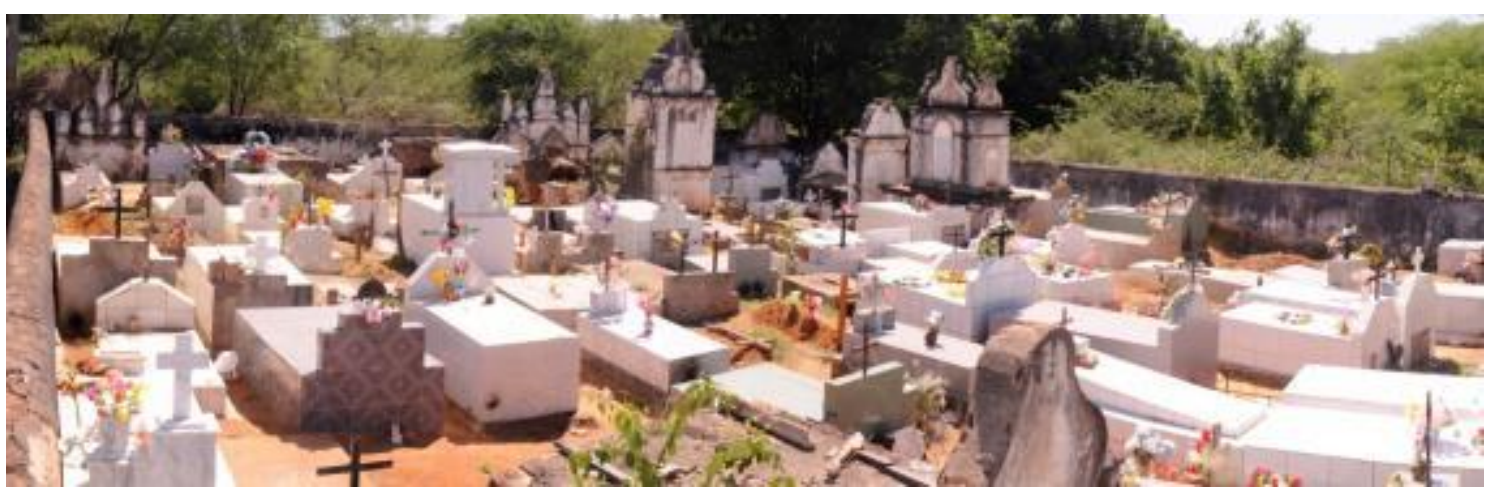

Figura 11: Vista geral do interior do Cemitério Nossa Senhora de Lourdes. Vista em direção a sudeste.

Foi possível observar, nesta pesquisa, no entanto, um padrão destoante com este costume, já que, nos 146 jazigos identificados, prevalece a orientação da cabeceira para Oeste (86\%), enquanto apenas $12 \%$ dos jazigos possuem orientação para leste. Vale ressaltar que apenas um único mausoléu encontra-se na direção norte e em dois jazigos não foi possível encontrar nenhum indício de orientação.

Visualizado a distribuição espacial das orientações das cabeceiras dos jazigos (Figura 12) é possível observar que não existe uma relação entre as orientações e sua localização na área do cemitério, sendo bastante aleatória a distribuição dos jazigos de orientação para o leste em relação aos jazigos com orientação para oeste.

No cemitério Nossa Senhora de Lourdes se encontram um total de cinco mausoléus preservados e com identificação, três estão preservados, porém, sem identificação. Quatro mausoléus encontram-se parcialmente destruídos, com alguns sendo possível apenas visualizar estruturas em avançado estado de degradação sendo utilizados constantemente como lixeiros (Figura 13). 


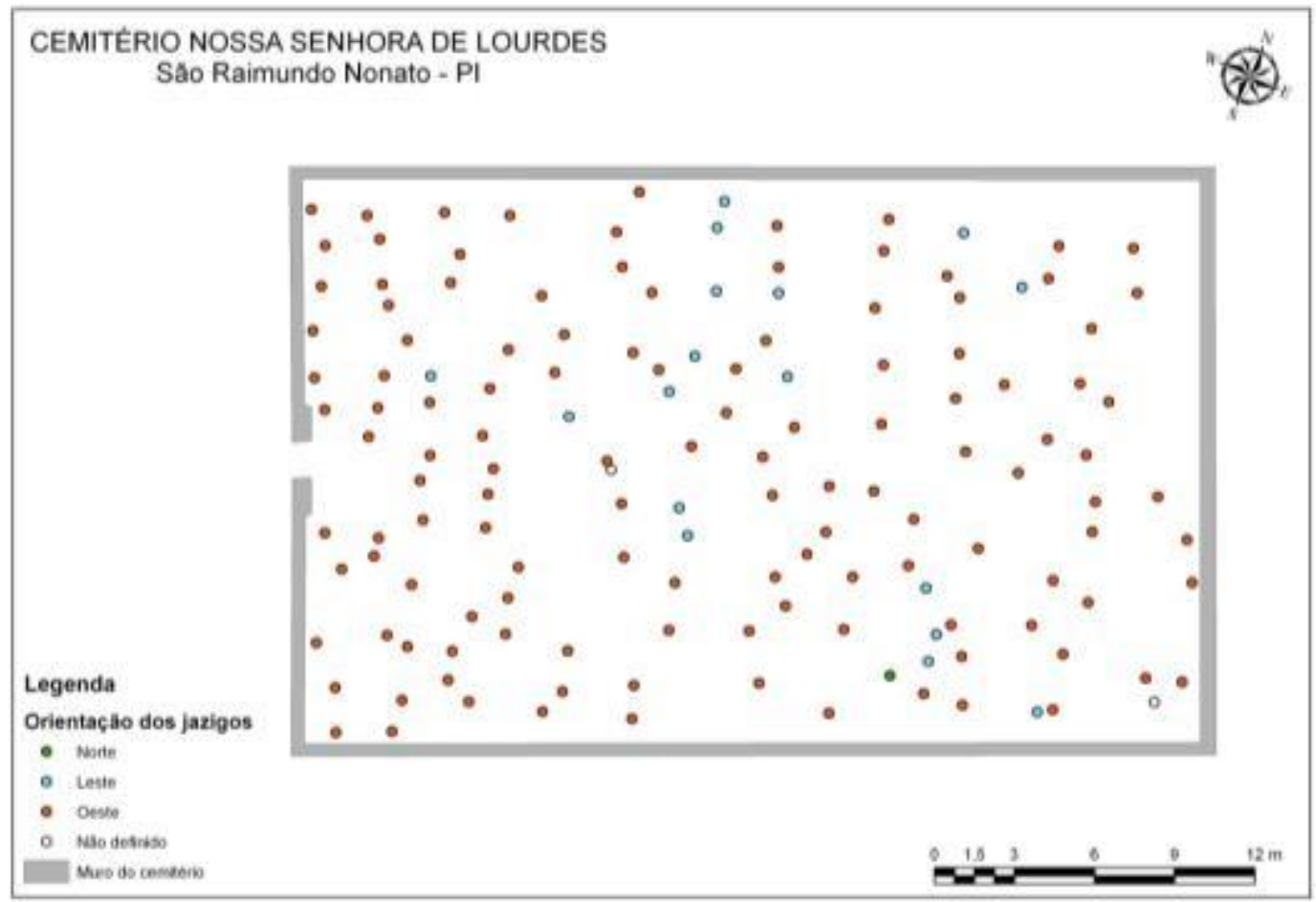

Figura 12: Distribuição das cabeceiras dos jazigos no Cemitério Nossa de Lourdes.

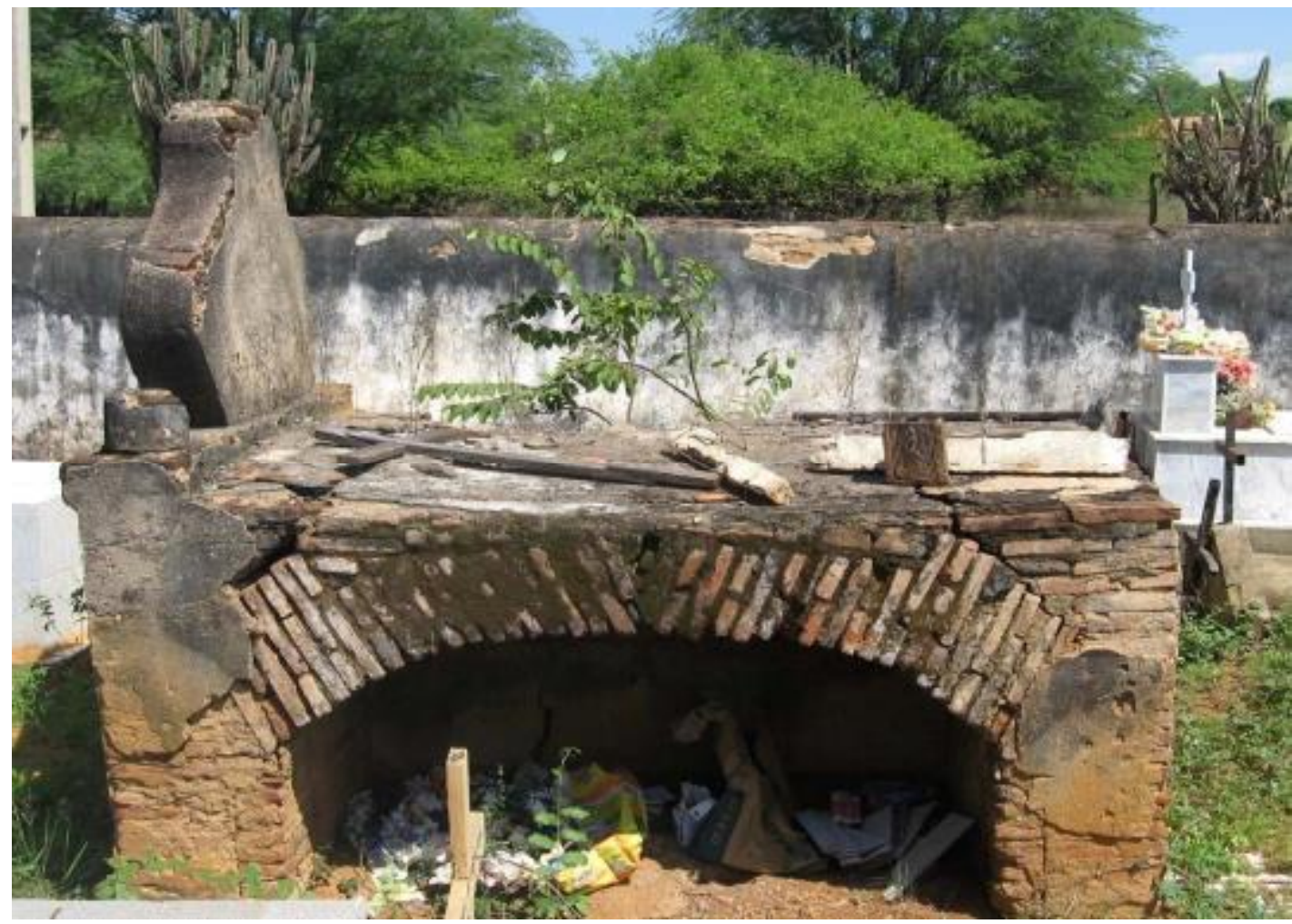

Figura 13: Mausoléu parcialmente destruído utilizado para depositar materiais e/ou lixo. 
Quanto às proporções das estruturas apresentadas, os mausoléus são na maioria de médio porte, alguns chegam a ter $4 \mathrm{~m}$ de altura, porém têm em média de $2 \mathrm{~m}$ a $3 \mathrm{~m}$ de altura. $\mathrm{O}$ que os diferencia são as formas e proporções, mas, em parte, constituem estruturas muitos simples que vêm acompanhadas de alguns detalhes como símbolos iconográficos o que os diferenciam dos outros jazigos (Figuras 14 e 15).

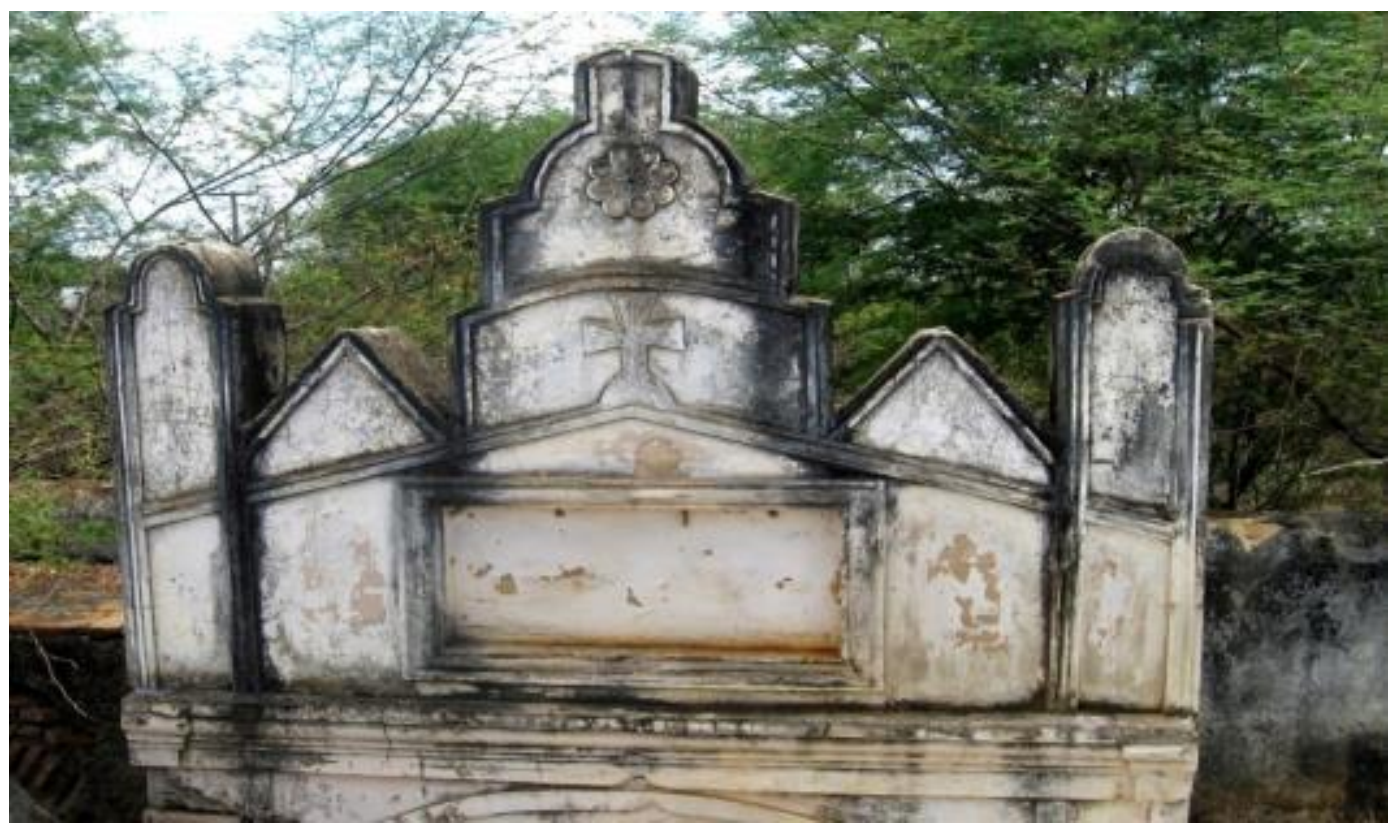

Figura 14: Mausoléu sem nenhuma identificação, destaque para a representação iconográfica, em detalhe do elemento arquitetônico caracterizado por uma flor e uma cruz.

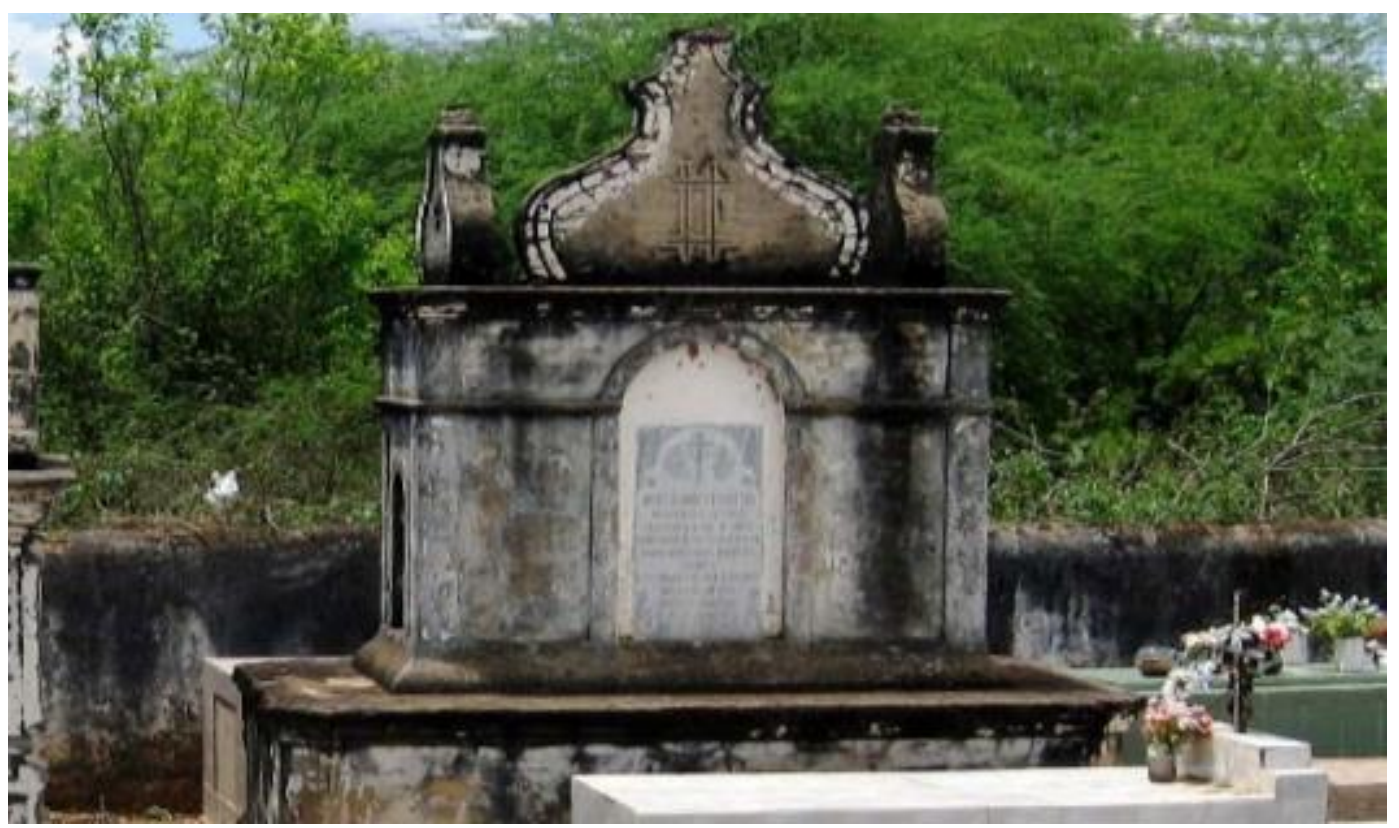

Figura 15: Mausoléu com 4m de altura. Este se diferencia dos demais jazigos por estar com sua orientação voltada para o Norte.

Quanto aos tipos de revestimento encontrados nos jazigos do cemitério Nossa Senhora de Lourdes, percebe-se que há uma relação bastante equitativa entre os materiais construtivos 
que recobrem esses jazigos. A distribuição dos revestimentos dos jazigos também mostra-se bastante aleatória na área interna do cemitério (Figura 16).

Foi possível identificar alguns padrões construtivos relativos aos diferentes tipos de revestimento encontrado nos jazigos, o azulejo, na cor azul ou branca, foi encontrado em 33 jazigos; a cerâmica, geralmente decorada, aparece revestindo 31 jazigos; o cimento aqui na cor cinza reveste 33 jazigos; cimento coberto com cal em 3 jazigos; 4 jazigos foram construídos em mármore, 42 jazigos não possuíam qualquer revestimento, sendo apenas identificados através de montículos de terra com uma cruz fincada na cabeceira, destes últimos, três possuíam uma cerca ao seu redor.

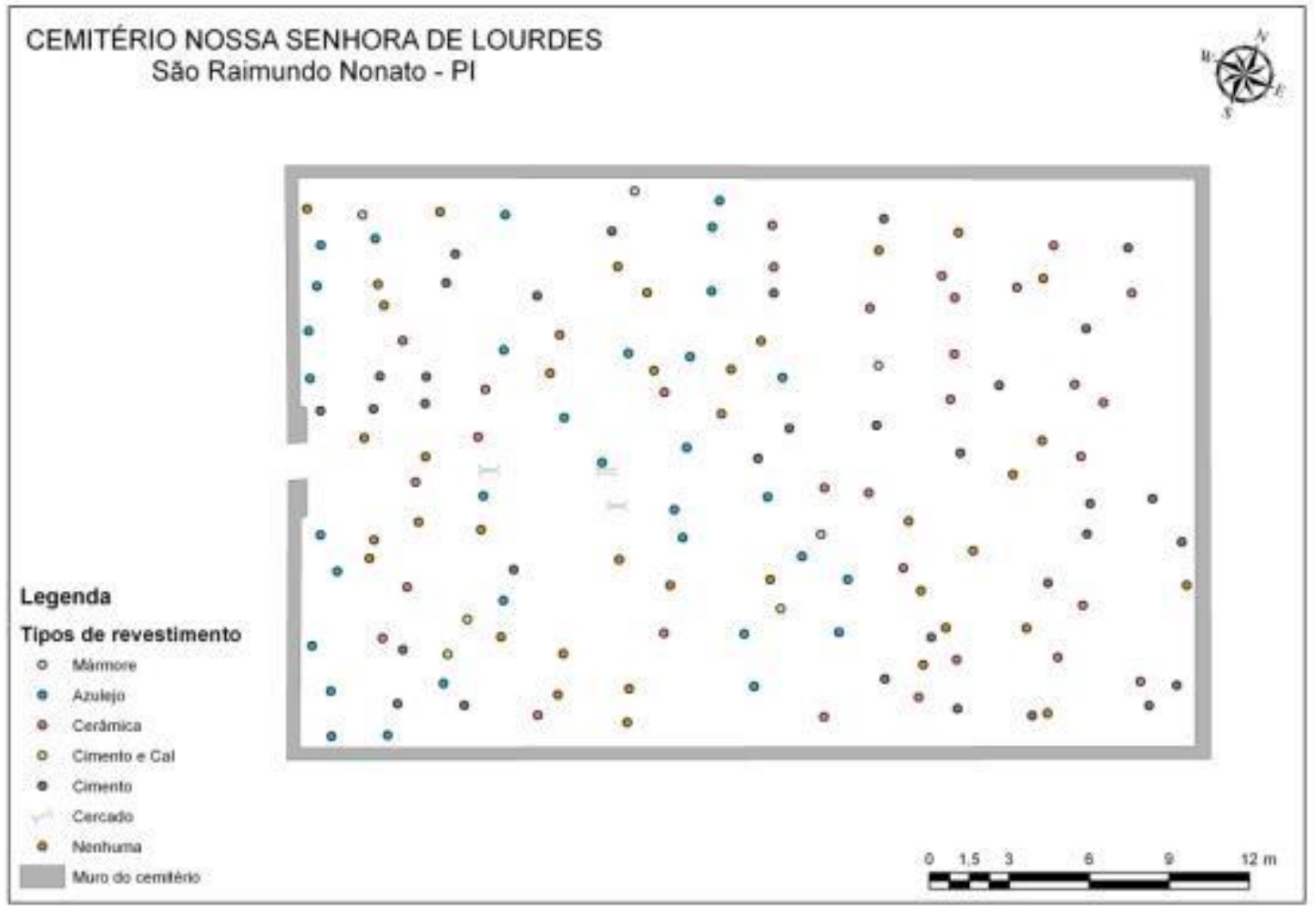

Figura 16: Distribuição dos tipos de revestimentos encontrados nos jazigos do Cemitério Nossa Senhora de Lourdes.

Mesmo que os tipos de revestimentos se mostrem bastante aleatórios espacialmente no cemitério, é possível visualizar uma evolução da utilização destes durante as décadas (Gráfico 1). Observa-se que até a década de 1920 o revestimento utilizado era apenas o cimento, enquanto, depois de um período sem dados sobre jazigos (1930-1940) o revestimento mais utilizado é o azulejo até a década de 1980, quando outros materiais começam a ser utilizados. Pode-se definir três momentos: 1880-1920, com utilização exclusiva do cimento como revestimento; 1950-1970, utilização quase exclusiva de azulejos como revestimento; e 19802000 quando vários materiais construtivos passam a ser utilizados como revestimento dos jazigos. No entanto, esta variação pode ser decorrente da quantidade de jazigos da década de 1990 em diante ser bem superior às décadas anteriores. 
Gráfico 1: Variação dos materiais construtivos no decorrer das décadas no Cemitério Nossa Senhora de Lourdes.

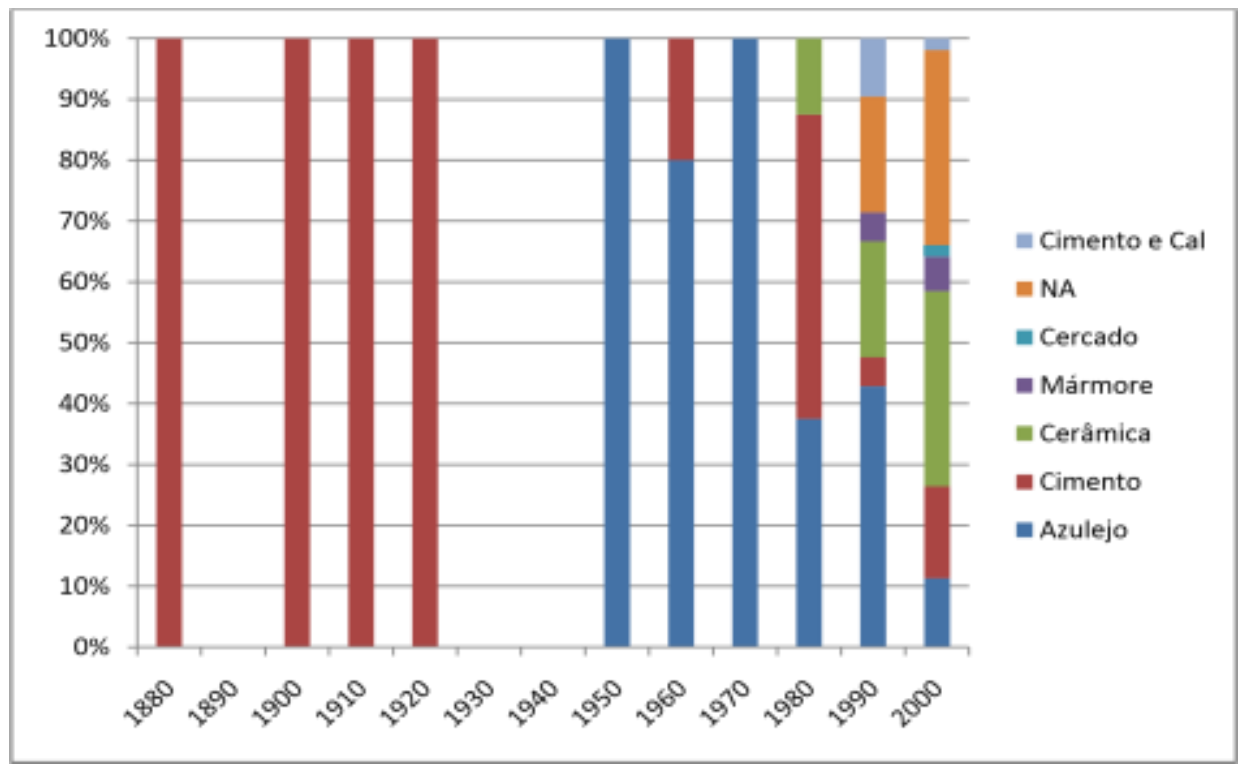

A análise da distribuição dos jazigos no decorrer das décadas permitiu a evidenciação de um período no qual não ocorreram sepultamentos, entre os anos de 1930 - 1940. Provavelmente esse seria o período em que o cemitério passou não realizar sepultamentos, estando interditado. Contudo, entre os anos de 1880 a 2000, houve um aumento considerável dos sepultamentos no Cemitério Nossa Senhora de Lourdes. Na década de 2000 observa-se que houve 54 sepultamentos, indicando que está atualmente em plena atividade.

No início da pesquisa ponderou-se ser possível identificar uma ordenação na distribuição espacial dos jazigos em relação às décadas, pois poderia haver uma área prioritária no cemitério pelo qual os sepultamentos mais antigos estariam preservados. No entanto os dados os dados em planta-baixa (Figura 17) não apontam para confirmação dessa hipótese. As únicas áreas que tem uma relação cronológica muito forte são a área noroeste do cemitério, na qual é possível observar uma fileira de jazigos da década de 1960 e que são da mesma família e na área sudoeste, também existindo uma fileira de jazigos da década de 1970, também pertencentes a uma mesma família.

Ao analisar o gráfico 2 é visível o considerável número de jazigos sem informações cronológicas, sendo muito provável que anos atrás houvesse uma freqüência grande de sepultamentos e por qualquer outro motivo ou interferência, não tiveram o controle dos sepultamentos ali existentes.

Observa-se neste trabalho que existem pouquíssimos jazigos contendo lápides no Cemitério Nossa Senhora de Lourdes. A distribuição das lápides no cemitério Nossa Senhora de Lourdes pode ser considerada relacionada à cronologia, já que a maioria das lápides pertence a jazigos mais antigos. Existe uma grande concentração de lápides na parte oeste do cemitério, relacionadas às décadas de 1960-1970 (Figura 18). Existe um total de 26 jazigos com lápides no cemitério. 


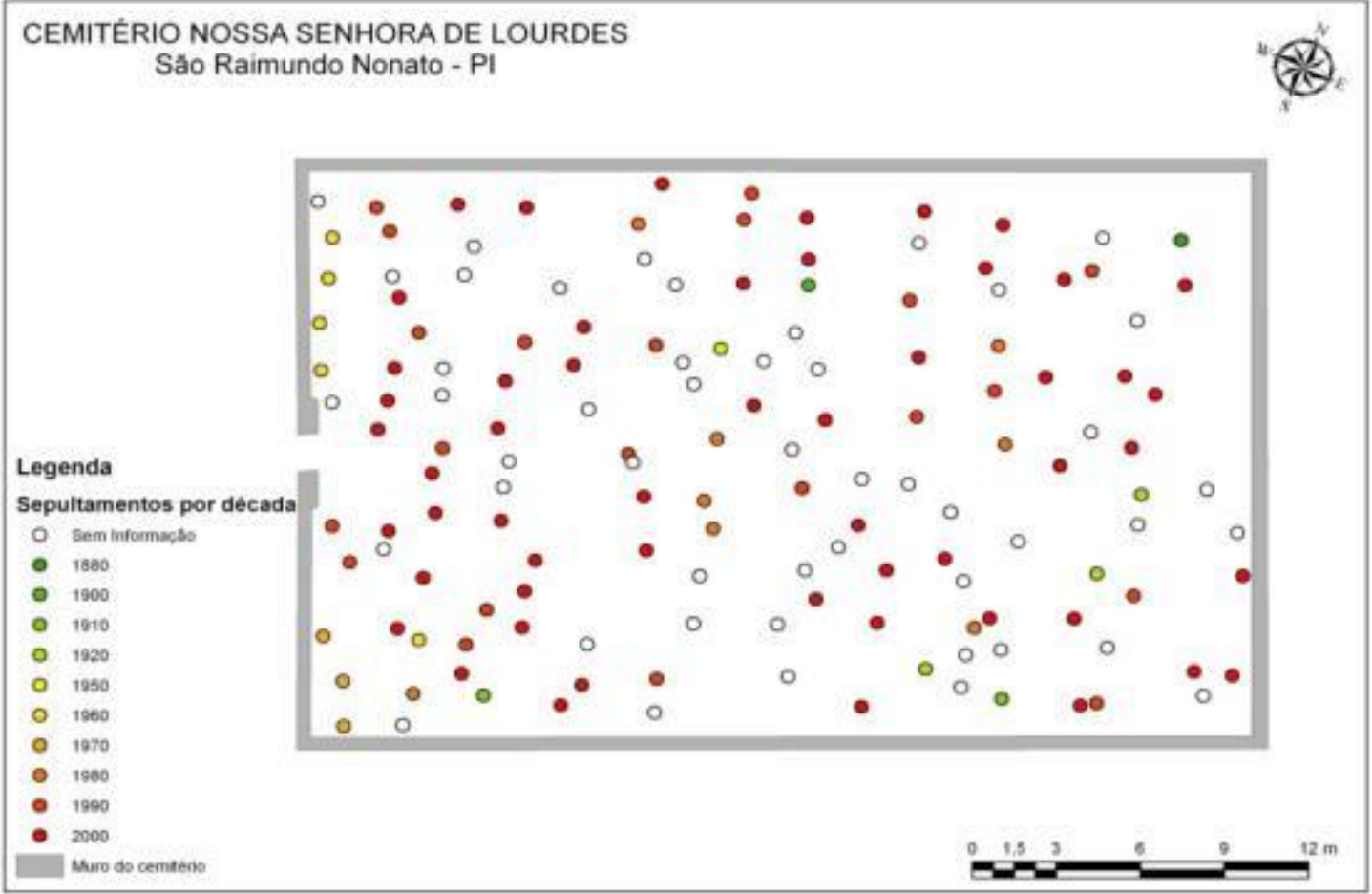

Figura 17: Mapa dos sepultamentos por década. Fonte: Laboratório de Geoprocessamento - Fumdham, 2009.

Gráfico 2: Jazigos do Cemitério Nossa Senhora de Lourdes no decorrer das décadas de 1880 a 2000.

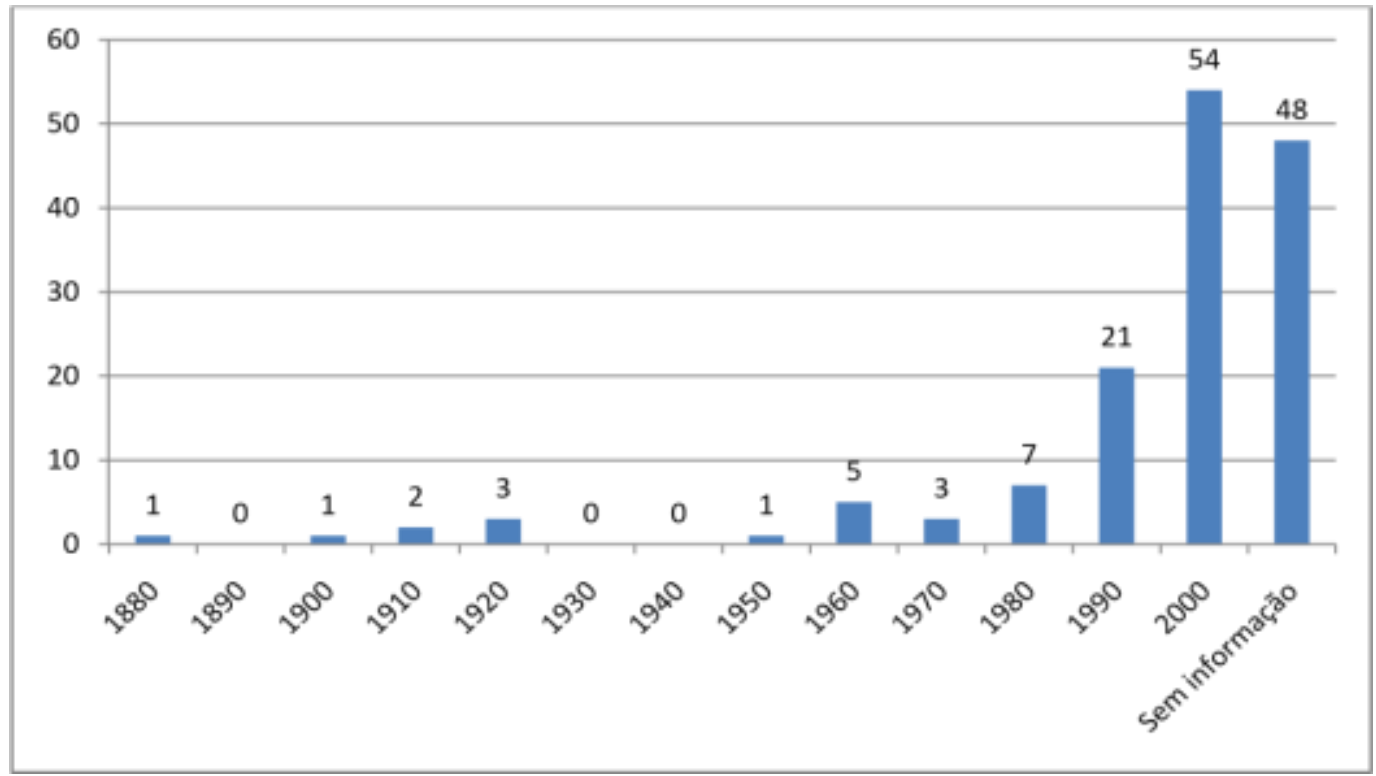

Tendo em vista todos os dados acima abordados, analisou-se também a porcentagem de óbitos do sexo masculino e feminino no cemitério Nossa Senhora de Lourdes, além de averiguar a idade de falecimento das pessoas sepultadas, e qual a idade média de falecimento para ambos os sexos. 


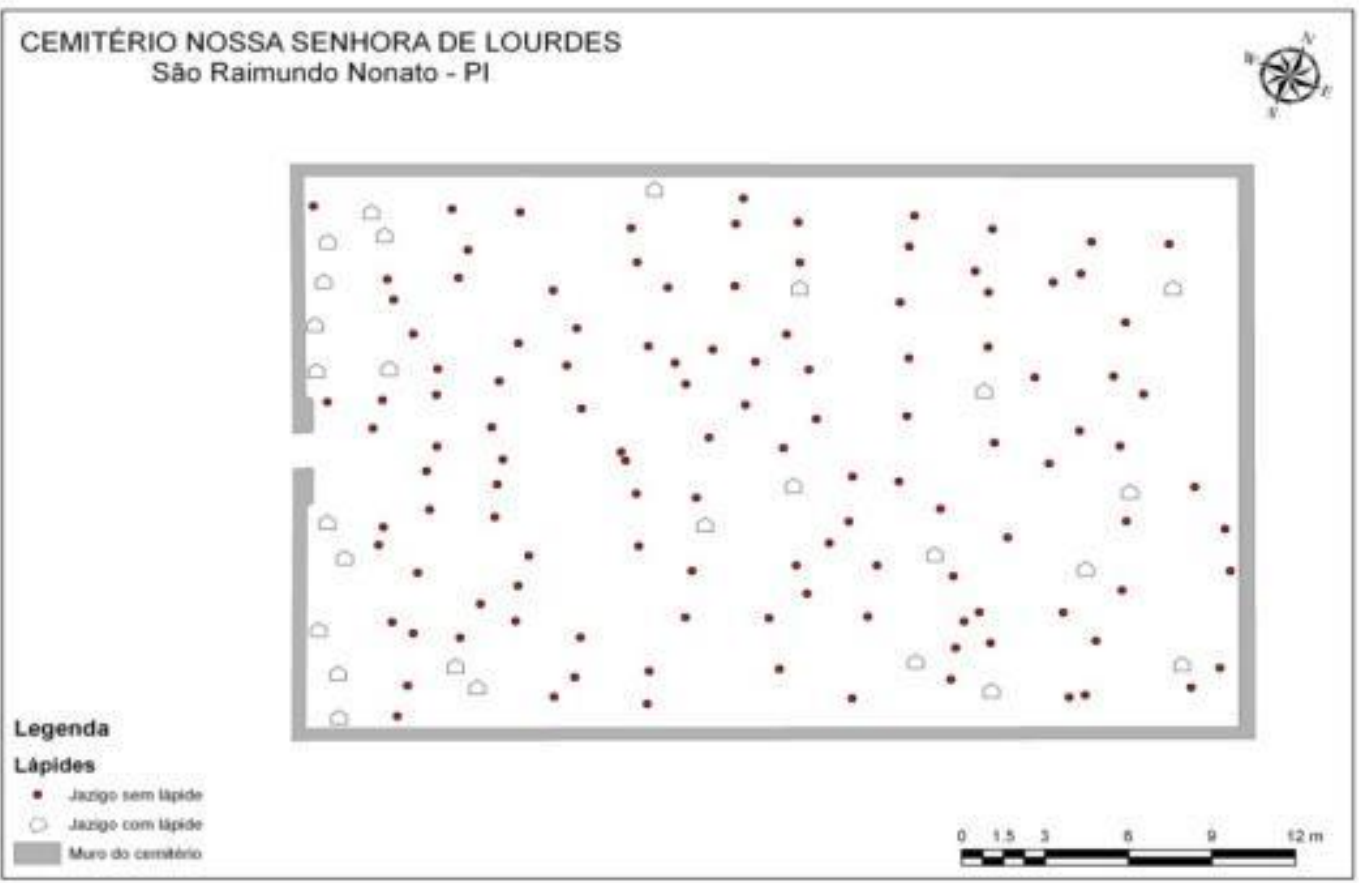

Figura 18: Mapa que identificar a quantidade de lápides no Cemitério Nossa Senhora de Lourdes.

Observou-se a predominância do sexo masculino no número de sepultamentos no Cemitério. Do total de 146 sepultamentos, $42 \%$ eram homens e $24 \%$ eram mulheres, enquanto $34 \%$ são jazigos que não possuem nenhuma informação sobre o sexo do falecido, já que não contém o nome do mesmo.

A idade de falecimento dos sepultados no Cemitério Nossa Senhora de Lourdes, são em geral, de pessoas acima de 60 anos, podendo indicar evidências de mortes de causas naturais. É notável a pequena a parcela de jovens e adolescentes, enquanto a existência de algumas crianças está relacionada a mortes nos primeiros anos de vida, no qual foi possível identificar duas crianças que faleceram no mesmo dia do seu nascimento.

A partir dos dados de idade de falecimento e de sexo dos sepultados no cemitério Nossa Senhora de Lourdes procurou-se fazer uma estimativa da idade média de falecimento dos mesmos. Foi possível constatar que as mulheres tinham uma expectativa de vida superior em mais de 10 anos a dos homens.

O jazigo mais antigo trata-se de um mausoléu, datado do ano de 1886. Provavelmente essas estruturas pertenciam a famílias tradicionais, de maior poder econômico, que buscavam ostentar na construção e na ornamentação de seus jazigos a riqueza desse período. Essas estruturas apresentam proporções de grande porte, normalmente são carregadas de elementos decorativos com apropriações arquitetônicas livres.

Todos os mausoléus estão localizados cronologicamente entre 1886 e 1927. Convém ressaltar que na maioria destes não constam informações que identifiquem a pessoa ali sepultada. 
Tendo em vista as referências citadas acima, vale ressaltar a construção destes grandes jazigos justamente na época de maior evidenciação econômica da região devido à extração da maniçoba em São Raimundo Nonato. Outro dado a ser observado é com relação às famílias mais pobres, as quais não tinham tal privilégio. A maioria dos jazigos desta época são mausoléus, contendo apenas dois túmulos, que, mesmo assim, são bastante decorados em relação ao contexto atual. Os jazigos mais simples desta época, provavelmente foram destruídos para dar mais espaço à novos sepultamentos ou os sepultamentos das pessoas mais pobres eram realizados em outro espaço funerário.

De modo geral todos os jazigos do cemitério de Nossa Senhora de Lourdes guardam particularidades especiais que expressam o cuidado dos familiares, desde a ornamentação do jazigo, as dedicatórias e as memórias transcritas nos epitáfios. Alguns jazigos chegam a possuir imagens sacras que muitas vezes são idolatradas nas igrejas ou trazem consigo um santo de devoção sobre o túmulo.

Os jazigos que continham lápides, selecionados para essa análise, constituíram um total de 26 no cemitério Nossa Senhora de Lourdes. As datas de sepultamento que contém lápides começam no ano de 1901 e vão até 2007. Nota-se o salto que foi dado de 1927 para 1963 (Gráfico 3). Ficando evidente um hiato cronológico.

Gráfico 3: Quantidade de lápides no decorrer das décadas.

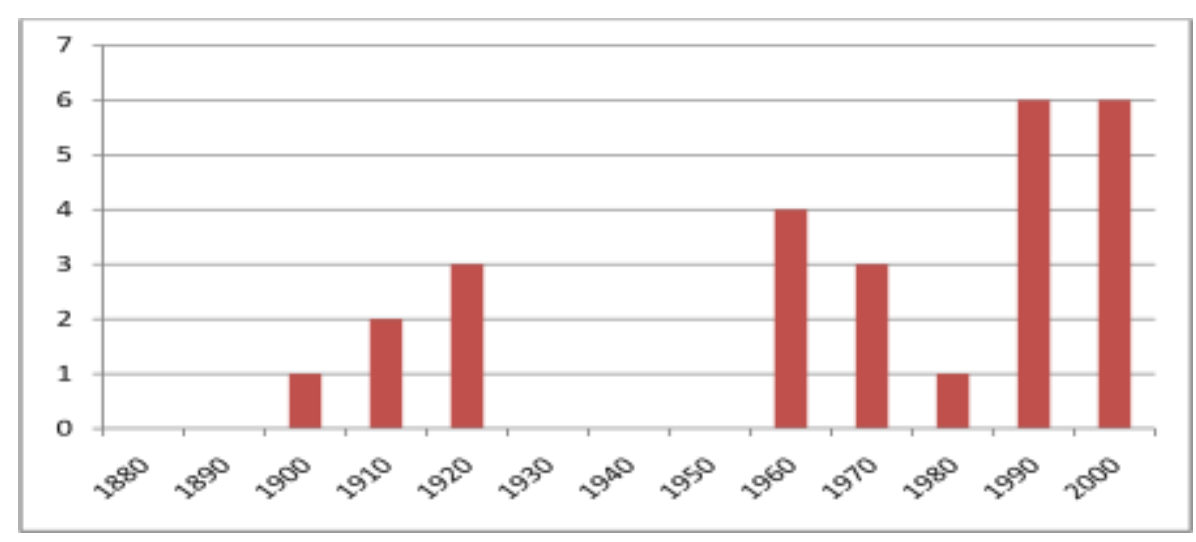

Antes da análise das lápides propriamente dita foi realizada uma caracterização dos elementos simbólicos que aparecem nos mausoléus do Cemitério Nossa Senhora de Lourdes. Estes elementos só aparecem neste tipo de jazigo. Mesmo não contendo uma lápide, foi analisado também o mausoléu mais antigo do cemitério, por possuir símbolos iconográficos. Este mausoléu apresenta uma estrutura que lembra a fachada de uma igreja. É comum a presença de duas torres nas laterais e de uma estrutura central que poderia ser a representação de uma cruz, no cruzamento vertical e horizontal se encontra um símbolo similar a representação do sagrado coração de Jesus de ponta a cabeça na parte da cabeceira, com orientação para o oeste, em sua base ao leste encontra-se o mesmo símbolo só que em posição contrária. 0 material construtivo utilizado é o cimento, não possui lápide, suas dimensões são $1,84 \mathrm{~m}$ largura; $2,30 \mathrm{~m}$ comprimento e $3,00 \mathrm{~m}$ altura.

Com base nas representações iconográficas identificadas nos mausoléus do Cemitério Nossa Senhora de Lourdes, localizou-se um total de seis estruturas que apresentam símbolos 
iconográficos. Visualiza-se essas expressões enquanto categorias tipológicas (Tabela 2). Os símbolos aqui encontrados são vistos como atribuições livres de decoração, no entanto buscou-se identificar elementos que tivessem algum significado religioso. Porém devido aos poucos dados existentes e à grande variabilidade, não foi possível interpretá-los de forma evolutiva, mas apenas como formas decorativas. Já na análise das lápides foi possível interpretar mudanças bem definidas na sua forma de apresentação.

Tabela 2: Freqüência dos símbolos iconográficos identificados nos mausoléus do Cemitério Nossa Senhora de Lourdes.

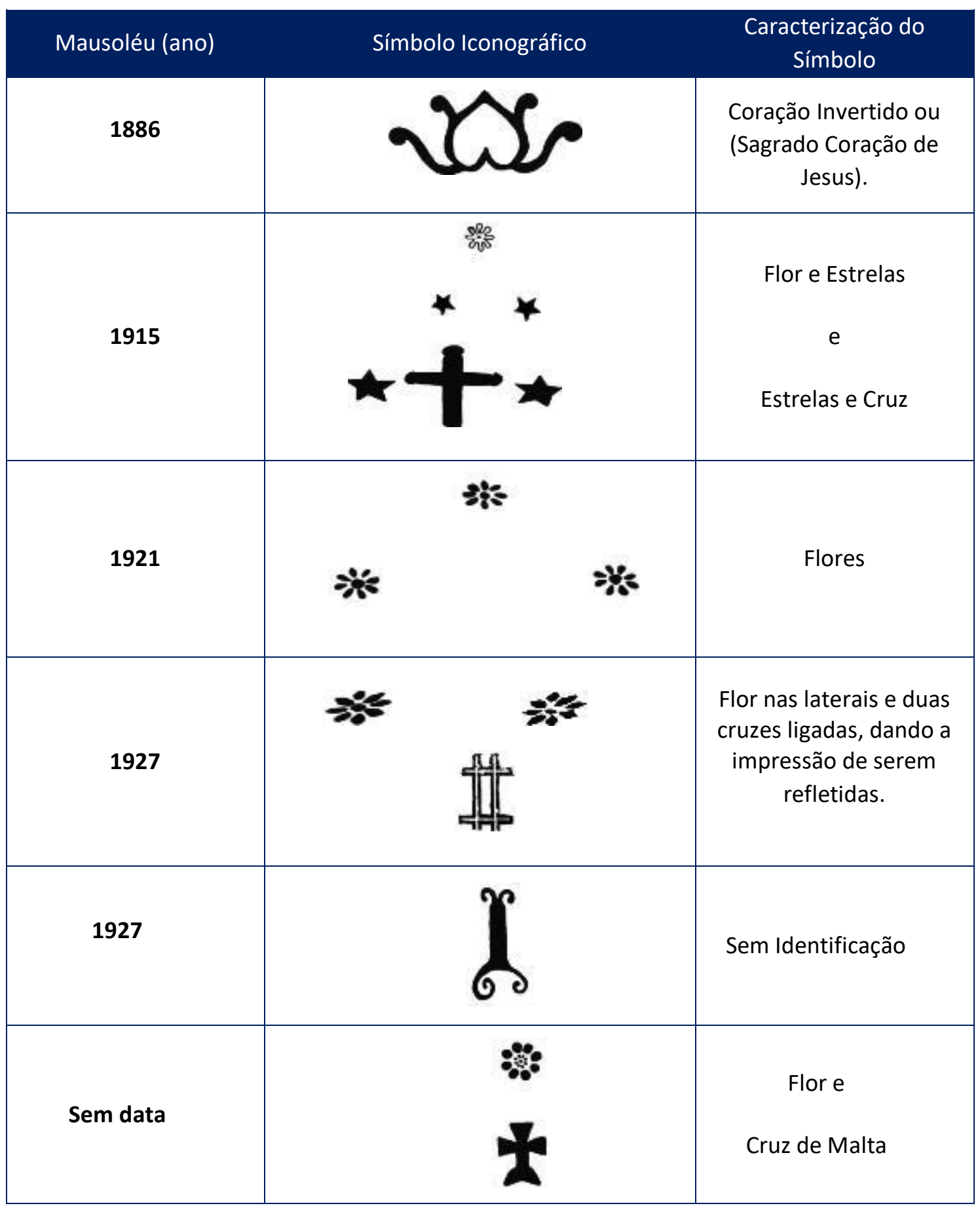




\section{Caracterização das lápides}

O túmulo mais antigo com presença de lápide data de 1901, parcialmente preservado foi fabricado em tijolo, possuía uma cobertura de cimento ainda visível, apresenta lápide em mármore lapidado com detalhes ornamentais, por cima do túmulo identifica-se dois jarros um na cor azul e outro transparente. Não possui cruz, mais pela posição de sua lápide identifica-se que ela está voltada para o nascente. Suas dimensões são 1,03m largura; 1,94 m comprimento e $0,50 \mathrm{~m}$ altura.

Sua lápide apresenta a frase "Aqui Descanca" e encontra-se escrita numa faixa que possui nas duas extremidades detalhes envolvido por uma cruz com galhos e dois botões com flores (Figura 19A). As letras são gravadas no mármore, sendo muito provável que as inscrições tenham sido pintadas e por ações de agentes intempéricos perdeu-se com o tempo. A lápide apresenta um formato retangular com inscrição muito simples, no canto direito identifica-se ainda o nome (BRITTO) gravado; ao que tudo indica seria o nome da marmoraria que a confeccionou.

O mausoléu datado do ano de 1915 (Figura 19D) possui uma estrutura que faz lembrar uma coluna com detalhes acrescida de frisos. As representações iconográficas existentes são em alto relevo e constituem de três símbolos na parte superior sendo uma flor no topo e duas estrelas nas laterais, na parte do meio do jazigo a lápide em mármore, na base detalhe de uma cruz ao centro e duas estrelas nas laterais. O material utilizado para a confecção desse mausoléu foi o cimento pintado na cor branca. A lápide possui a forma de um porta-retrato com bordas em alto relevo no formato retangular, acompanhado das inscrições lapidadas em mármore, sendo gravadas e pintadas na cor preta. A lápide possui uma decoração que lembra uma coroa com flores seguida da informação sobre o falecido e um epitáfio simples.

O próximo jazigo possui características morfológicas de um túmulo, o material construtivo utilizado foi o cimento. Data do ano de 1917 sendo do mesmo período dos mausoléus, ou seja, do início do século XX. Há a ausência de elementos iconográficos, o único detalhe decorativo encontrado resumido à própria lápide. As proporções do jazigo chegam a 1,17 m de largura; $2,21 \mathrm{~m}$ de comprimento; $1,74 \mathrm{~m}$ altura. Sua orientação está para Oeste. Foi confeccionado em cimento, não possui cruz, as inscrições em alto relevo.

Pode-se inferir sobre essa lápide que é bem diferente das demais, possui ilustração no mármore lapidado de expressiva beleza, as letras são gravadas em alto relevo no topo da lápide trazendo a representação de ramos que lembram fitas (Figura 19C). Está escrito em seu epitáfio:

\section{Aqui Descançam \\ Os Restos Mortaes de \\ Salomão Ribeiro \\ Nasceu a 10 de Setembro de 1885 \\ Falleceu a 3 de Novembro de 1917 \\ Saudade de sua Esposa e Filhos}

O próximo mausoléu apresentado constitui um monumento dado o seu porte e a riqueza de detalhes ornamentais. Possui uma cruz no topo, flores incrustadas, duas aberturas nas laterais 
que lembram um arco pleno além de possuir elementos que lembram frisos resumem a fachada de uma capela de cor branca, feita de cimento. Na parte de cima do jazigo possui quatro suportes sendo dois na frente e atrás, sendo muito provável que tivesse algum ornamento escultórico ao que tudo indica tenha sido quebrado.

A sua lápide possui elementos que foram lapidados no próprio mármore, as letras apresentam em alto relevo, ao centro as inscrições estão na cor branca, os detalhes nas bordas da lápide são na cor cinza sendo uma característica natural do próprio mármore, possui formato retangular, acima da inscrição, ou seja, no topo, apresenta elementos decorativos que nos fazem lembrar um laço, nos lados seguem ramos formando flores (Figura 19D).
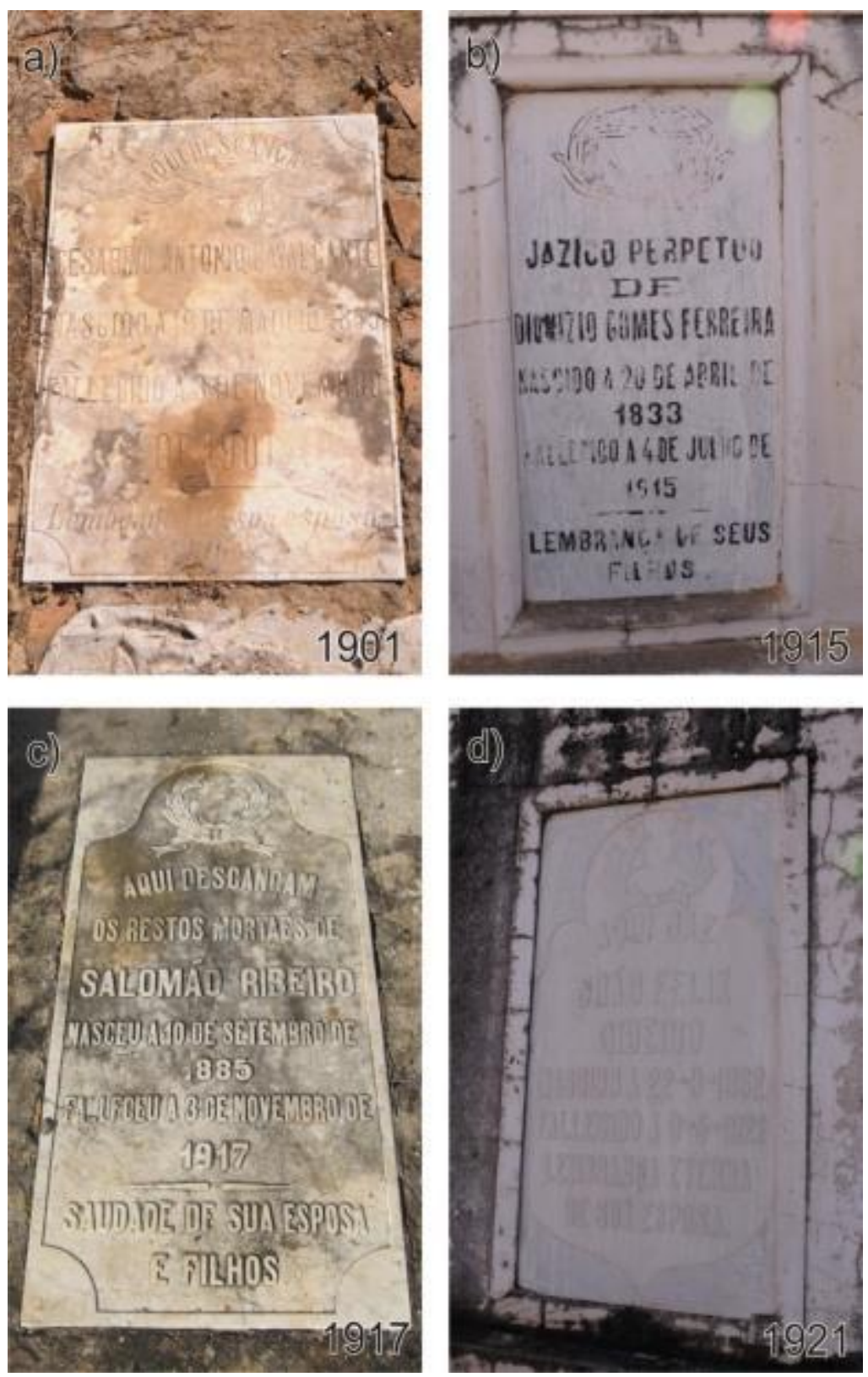

Figura 19: A,B,C e D. Lápides do início do século XX, dos anos de 1901, 1915, 1917 e 1921. 
O mausoléu de Angelo Gomes Ferreira é caracterizado pelo seu grande tamanho, sendo o maior jazigo do cemitério Nossa Senhora de Lourdes. Possui as dimensões 1,96m de largura; 3,35m de comprimento; $4 \mathrm{~m}$ de altura. Data de 1927 e possui orientação para norte. $\mathrm{O}$ jazigo foi confeccionado em cimento, possuindo como suporte escultórico três estruturas decorativas fixadas na parte de cima do jazido, lembrando um arco do triunfo, ainda sendo possível encontrar detalhes como frisos. Quanto aos detalhes decorativos da parte de cima do mausoléu encontram-se elementos iconográficos. No primeiro elemento encontrado localizase a imagem de uma cruz incrustada em alto relevo dar a impressão de serem refletidas, já as outras duas estruturas das laterais, possuem o mesmo formato sendo menores, nelas identifica-se uma flor em cada lado. A lápide encontra-se localizada no meio do jazigo, nas laterais do mausoléu, possuindo detalhes que lembram a forma de um arco pleno.

As inscrições da lápide do jazigo estão localizadas dentro de um arco pleno, a lápide possui formato retangular feito em granito com letras em alto relevo. Possui alguns elementos decorativos por toda lápide que nos lembram ramos com flores e laços, todos se misturam compondo a estrutura que possui uma cor cinza característica da própria pedra. A parte superior da lápide possui um símbolo que tem como representação uma cruz como se fosse ser envolvida por um laço (Figura 20A).

O mausoléu de Bráulio Miranda, também datado de 1927, tem dimensões menores do que os já comentados nesse trabalho, variando entre $1,50 \mathrm{~m}$ de largura, 2,20m de comprimento e $2,28 \mathrm{~m}$ a altura. Possui a orientação para oeste, o material construtivo que predomina é o cimento. Na parte superior do jazigo identifica-se um elemento decorativo não identificado.

A lápide, esculpida em mármore possui um elemento decorativo acima dos epitáfios que lembram uma coroa com ramos de oliveira envolvendo uma cruz, as inscrições estão em baixo relevo, ou seja, são talhadas no próprio mármore na cor preta, algumas letras estão apagadas por motivos de intempéries. O formato da lápide é retangular, as bordas sobressaem em alto relevo incrustado no cimento (Figura 20B).
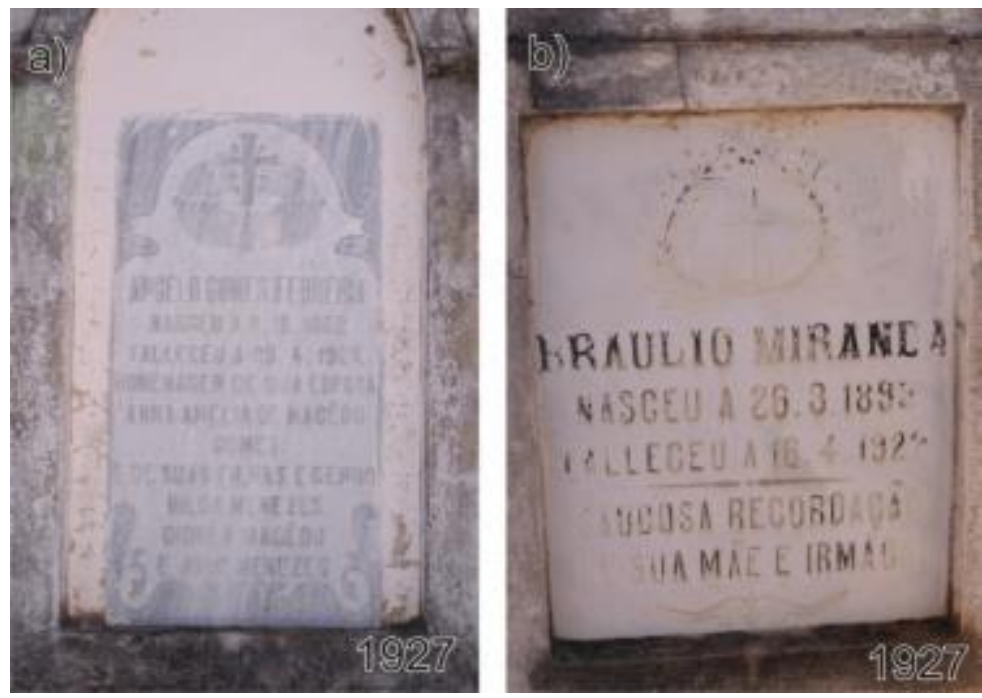

Figura 20: Lápides do início do século XX, do ano de 1927. 
Como visto anteriormente, depois destas lápides as próximas em escala cronológica só aparecem na década de 1960. O que prevalece nesses túmulos será a simplicidade dos jazigos tanto nas formas quanto no material utilizado (sem construções de grande pote como nos mausoléus), ficando por conta dos familiares enlutados a decoração em alguns jazigos predomina uma ausência nos ornamentos.

Os túmulos que contêm lápides da década de 1960 e 1970 possuem a mesma morfologia. 0 revestimento é em azulejo azul, com dimensões médias $0,80 \mathrm{~m}$ de largura, 1,85m comprimento e 0,65 $\mathrm{m}$ de altura. Apresentam as lápides próximas a cabeceira. Possuem todos, orientação para oeste e uma cruz trabalhada com detalhes feita em metal envolvida por um arranjo de flores (Figura 21).

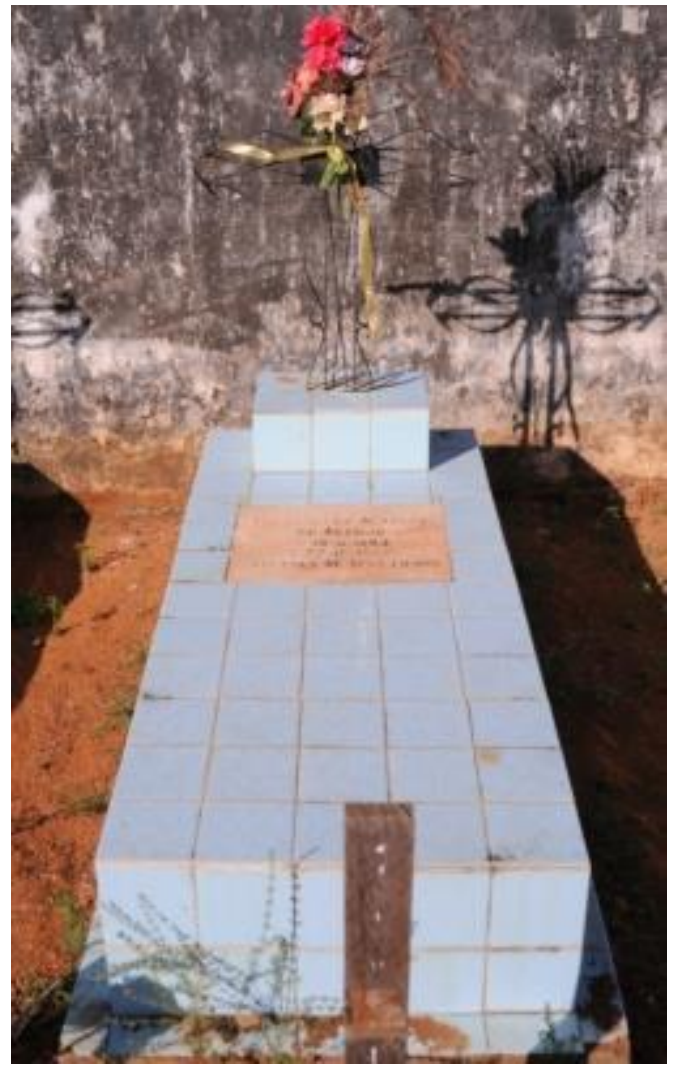

Figura 21: Túmulo com lápide típico das décadas de 1960 e 1970 no Cemitério Nossa Senhora de Lourdes.

As lápides da década de 1960 são bastante parecidas e pertencem todas a uma mesma família, a família Araújo. Estão localizadas próxima à cruz, o material utilizado foi o mármore.

As três lápides mais antigas, dos anos de 1963, 1965 e 1968 apresentam inscrições esculpidas apenas com o nome, datas de nascimento, falecimento e um pequeno epitáfio (Figuras 22A-C). As inscrições encontram-se um pouco apagadas, no entanto percebe-se que antes predominava a cor preta preenchendo as gravuras.

A lápide de Maria Stelita de Araújo Landim lembra um livro aberto representando a Bíblia Sagrada. As letras foram apagadas com o tempo, sofrendo desgaste por causa das intempéries (Figura 22D). 
As lápides da década de 1970 também se parecem bastante entre si, também pertencendo a uma mesma família, a família Pamplona. Diferem das da década de 1960 por possuírem uma área esculpida na área central da lápide fazendo com que as inscrições se apresentem em alto relevo (Figuras 23A-C). A única das três lápides que contém um epitáfio é a de Epitácio Alves Pamplona, sendo bastante sucinto Saudades Eterna escrito em alto relevo sobre o mármore logo abaixo da data de nascimento e falecimento (Figura 23C).

A única lápide da década de 1980 pertence a José dos Santos Sousa que está sepultado em um túmulo coletivo junto a Emilia Paes Landim Sousa. O túmulo apresenta como material de revestimento a cerâmica branca e decorada, sendo cruz e lápide em mármore com as inscrições pintadas de preto. $\mathrm{O}$ jazigo está com a cabeceira voltada para leste e possui vasos com flores naturais e artificiais. Suas dimensões são de 1,08m largura, 2,31 m de comprimento e $0,90 \mathrm{~m}$ de altura.

A lápide se apresenta de forma retangular, muito simples, sendo confeccionada em mármore branco. Possui apenas nome e data de nascimento e falecimento do morto (Figura 23D).

Na década de 1990 a morfologia das lápides torna-se mais variada, embora todas tenham como suporte o mármore. A morfologia dos túmulos continua muito próxima aos das décadas de 1960 em diante.

O túmulo do frei Manuel Antonio Rodrigues, datado de 1990, apresenta um revestimento em azulejo pequeno de cor branca, possui lápide e uma cruz trabalhada em metal. Nela encontrase um arranjo de flores e próximo da lápide um ramo de folhas como decoração. Um fato em especial chamou nossa atenção para com este jazigo, já que ele pertenceu a um vigário desta cidade, por não encontrar-se sepultado na igreja. Em entrevistas com moradores das redondezas próxima ao cemitério obtive informações que frei Manuel encontra-se ali sepultado por um pedido do mesmo para que fosse sepultado nesse cemitério pelo fato de ter uma roça ao lado deste e que, quando em vida, expressou, antes de vim a falecer, o desejo de ser sepultado no cemitério. Teria afirmado que era uma forma de estar vigiando sua roça e que iria estar sempre a vigiar.

A lápide possui o nome do falecido, data de nascimento e falecimento. As inscrições são muito simples gravadas em alto relevo no próprio mármore branco, à exemplo das lápides da década de 1970. Apresenta algumas partes enegrecidas devido a presença de fungos. Na lápide ainda observa-se a sigla D.E.P que significa Descanse em Paz (Figura 24A).

O túmulo pertencente ao Sr. Luciano de Castro Baião, também data do ano de 1990. Está orientado para oeste, possui cruz em metal na cor preta. Nela identifica-se ainda o ano de nascimento e falecimento pintados em branco. Há uma completa ausência de elementos decorativos. O revestimento utilizado foi o azulejo. A lápide está localizada ao centro do jazigo. 

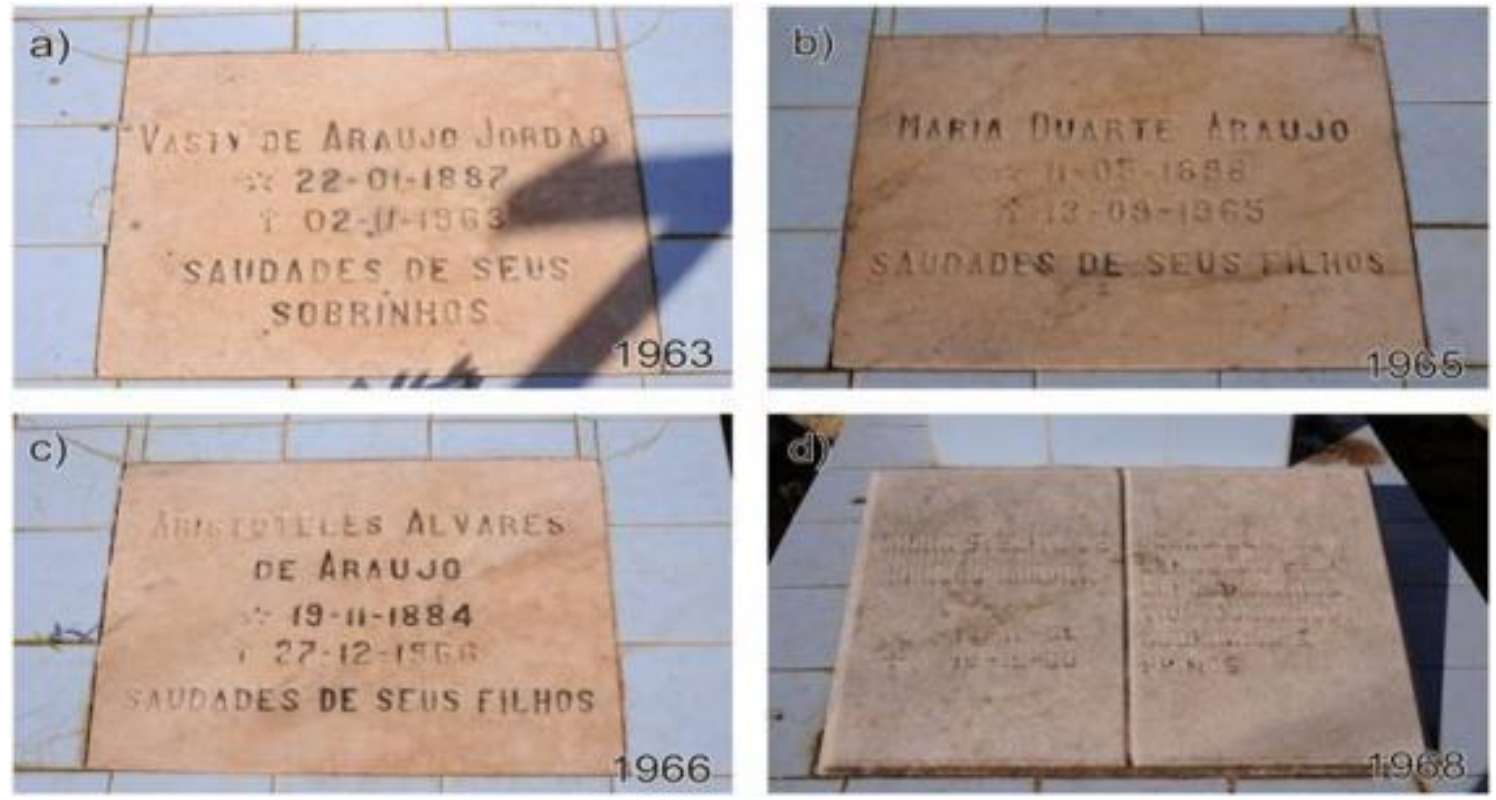

Figura 22: A, B, C, D. Lápides da década de 1960, dos anos de 1963, 1965, 1966 e 1968.
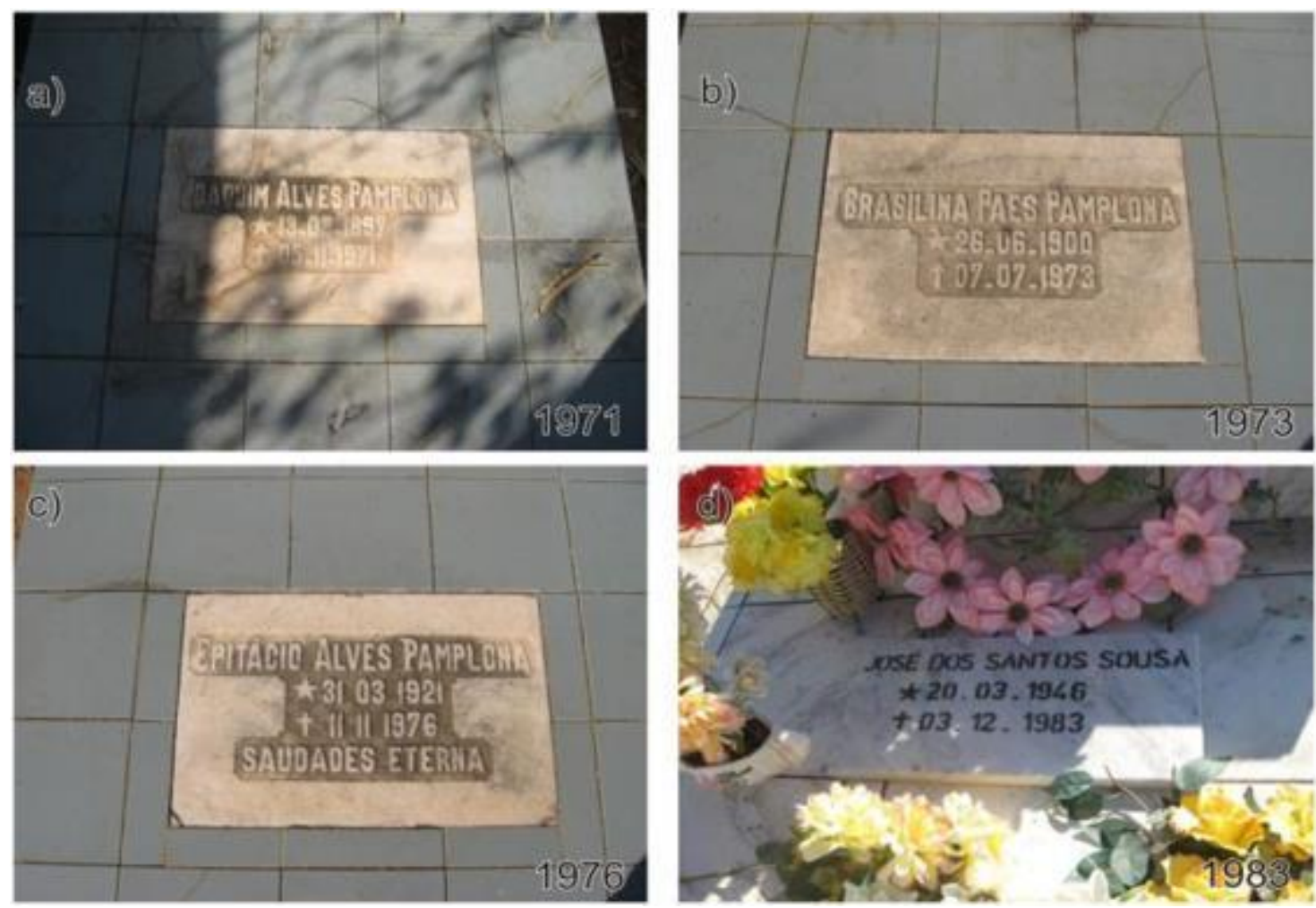

Figura 23: A, B, C, D. Lápides das décadas de 1970 e 1980, dos anos de 1971, 1973, 1976 e 1983.

A lápide possui formato retangular confeccionado em mármore branco. Suas inscrições foram feitas com um leve incrustamento na placa, o que nos faz lembrar riscos na pedra. Apresenta uma cor amarelada devido à ação de intempéries, quase não é possível identificar o que está escrito nela. Possui epitáfio bastante simples que diz: Saudades daqueles que Amei na Terra. (Figura 24B). 

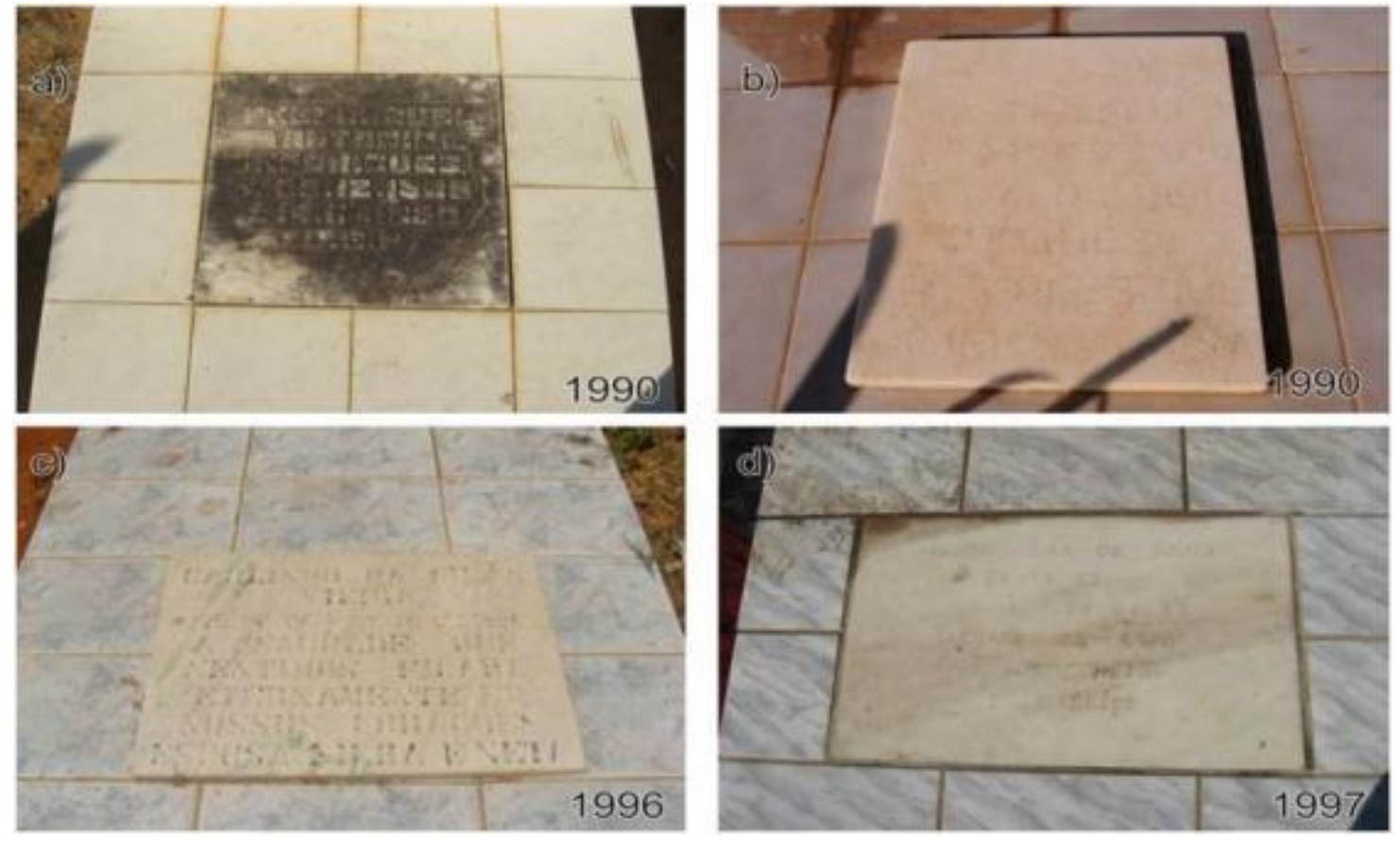

Figura 24: A, B, C, D. Lápides das décadas de 1990, dos anos de 1990, 1996 e 1997.

O túmulo do Sr. Carlindo da Silva Vieira traz uma lápide fixada ao final do jazigo. Apresenta revestimento em cerâmica decorada na cor azul-claro. Possui uma coroa de flores sobre uma cruz em metal de cor preta. Sua orientação está para oeste.

A lápide foi confeccionada em mármore branco, possuindo pigmentos na cor verde. É possível visualizar suas inscrições bastante apagadas, no entanto, ainda é possível identificar a cor preta na qual foi pintada anteriormente. As letras foram esculpidas na própria pedra. Possui a seguinte epigrafo: A saudade que sentimos ficará eternamente em nossos corações, esposa, filha e neto (Figura 24C).

O túmulo pertencente ao Sr. Antonio de Dias de Souza, possui uma cruz confeccionada em metal na cor preta e apresenta o revestimento em cerâmica decorada. O jazigo está ligado a outro túmulo e possui como decoração um vaso com flores. Está orientado para leste.

A lápide do túmulo possui formato retangular e foi confeccionada em mármore de cor branca. As inscrições nelas existentes foram esculpidas na própria pedra. Apresenta nome, datas de nascimento e falecimento e epitáfio muito simples (Figura 24D).

O túmulo de José Antônio da Silva está localizado no início do cemitério do lado direito próximo ao portão de entrada. Tem orientação voltada para oeste. Esse jazigo é datado do ano de 1999. Apresenta uma cruz em madeira, que se encontra apoiada somente na parede, não sendo fincada no jazigo. Identifica-se a lápide próxima à base do suporte, local sobre o túmulo onde normalmente fincam a cruz. O material utilizado como revestimento foi à cerâmica decorada com predomínio do branco. 
A lápide foi confeccionada em mármore com as informações do falecido esculpidas na pedra e pintada na cor preta. A lápide, como o jazigo, encontra-se bastante sujo. As únicas inscrições que constam na lápide são o nome e data de nascimento e falecimento do morto (Figura 25a).
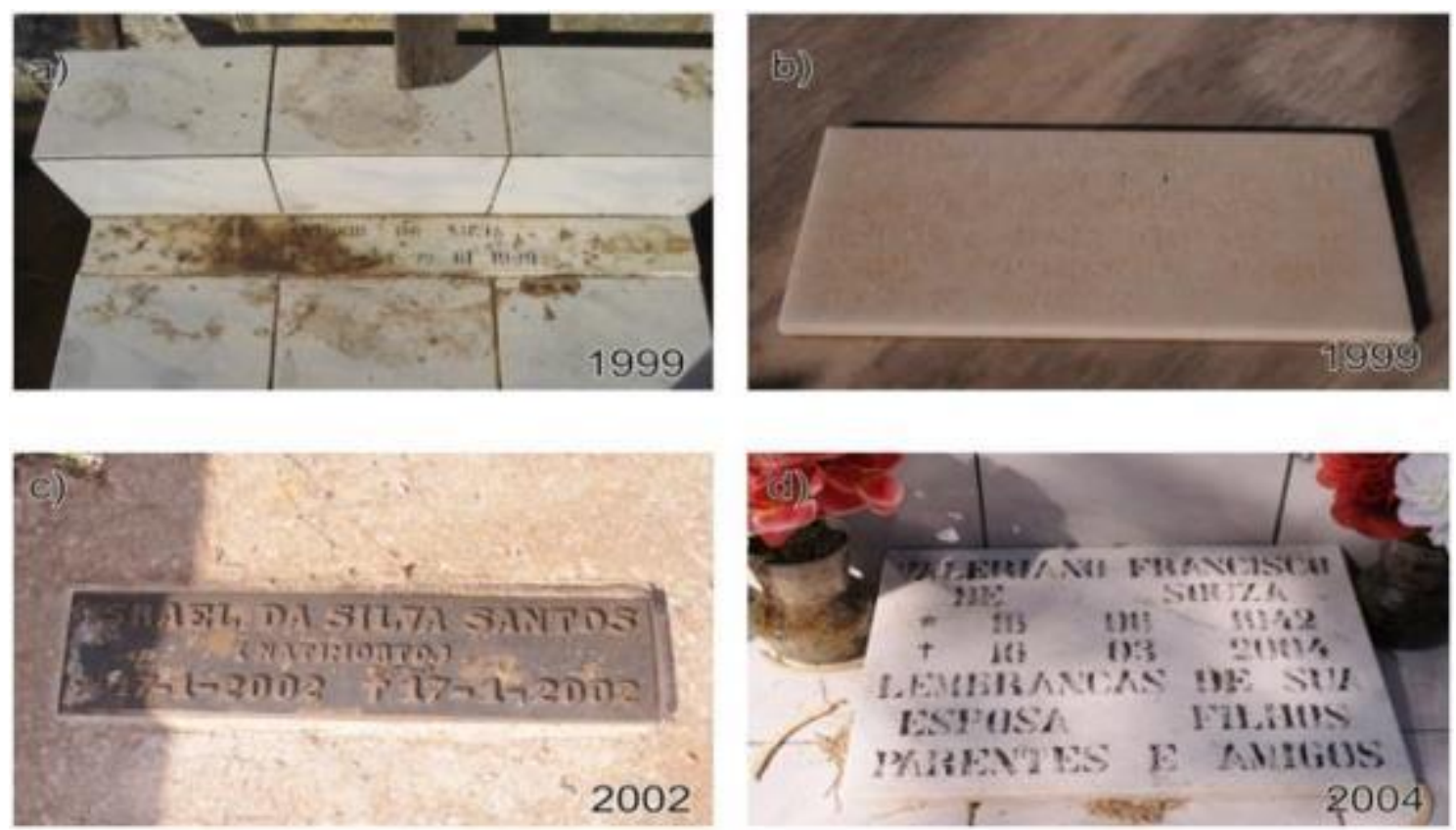

Figura 25: A, B, C, D. Lápides das décadas de 1990 e 2000, dos anos de 1999, 2002 e 2004.

Também do ano de 1999, o túmulo de Pedro Alcântara Baião foi inteiramente confeccionado em mármore. Apresenta um suporte em cima do túmulo com espaços reservados para fotos e um vaso para por flores, ambos encontra-se fixado à cruz (Figura 26). Possui uma lápide fixada em um retângulo na tampa do jazigo. Possui orientação voltada para oeste. $O$ jazigo encontrase disposto na parte norte do cemitério.

A lápide possui um formato retangular com inscrições gravadas no mármore branco. São utilizadas letras de fôrma, apresentando além do nome e datas de nascimento e falecimento os epitáfios com suas respectivas dedicatória: Pedro Alcântara Baião. Nascido em 23.04.49 e faleceu a 16.04.1999. Saudades eternas da esposa, filhos irmãos, sobrinhos, parentes e amigos (Figura 25B).

A seguir encontra-se um túmulo de um recém-nascido, confeccionado em cimento, do ano de 2002. Há a ausência de cruz e decoração, possuindo orientação para oeste. Suas dimensões são bastante pequenas: $0,47 \mathrm{~m}$ de largura, $0,87 \mathrm{~m}$ comprimento e $0,63 \mathrm{~m}$ de altura (Figura $25 \mathrm{C}$ ).

A lápide é uma pequena placa de metal na cor preta incrustada no cimento com identificação do nome e data de nascimento e falecimento, ainda possui ausência de elementos decorativos. Abaixo do nome localiza-se a inscrição natimorto (Figura 25C).

O túmulo pertencente a Valeriano Francisco de Souza encontra-se ao lado de dois mausoléus. Em ambos os lados é bastante difícil o acesso. Possui cruz e lápide em mármore branco. 0 revestimento utilizado na confecção foi a cerâmica. O jazigo está voltado para oeste. Há a 
presença de elementos decorativos como dois vasos com flores entre a lápide, e uma coroa de flores sobreposta na cruz.

A Lápide possui elementos bastante simples, confeccionada em mármore branco no formato retangular, possui inscrições pintadas e lapidadas na própria pedra. Apresenta identificação com nome, data de nascimento e falecimento e presença de epitáfio (Figura 25D).

O jazigo a seguir data do ano de 2005. Trata-se de um jazigo coletivo, já que existem duas pessoas sepultadas no mesmo. Sua estrutura é revestida de dois tipos de cerâmica, lisa e decorada na cor preta. Possui orientação para oeste e identificam-se elementos funcionais como dois assentos nas laterais do túmulo posto numa área em frente ao jazigo. Possui vasos, uma cruz de cor preta fincada sobre a cabeceira do túmulo feita de mármore, ainda há outra sobre túmulo na cor dourada. Há uma grande quantidade de flores sobre o túmulo. As dimensões deste são de 0,94m de largura;2,15 m de comprimento e 1,76 m de altura (Figura 38).

A lápide apresenta-se na forma de um retângulo divido em dois planos. A primeira apresenta nome do falecido e suas datas de nascimento e falecimento, na parte de baixo segue 0 epitáfio. No outro plano é colocada as informações da outra pessoa sepultada no túmulo. A lápide foi confeccionada na cor preto o material utilizado foi o mármore. Encontram-se ainda nesse túmulo, como decoração, duas vasilhas transparentes que são utilizadas para acenderem velas. Além de possuírem vasos com flores, os epitáfios apresentam tanto mensagens de saudades e uma passagem do evangelho (Figura 26A).

O túmulo a seguir foi confeccionado em cimento, possui ausência de ornamentos no próprio jazigo, apenas foi acrescido de elementos decorativos com três vasos com flores. Apresenta lápide simples e uma cruz em madeira com orientação para o oeste. Sua lápide foi confeccionada em mármore branco decorado, tendo o formato retangular. As inscrições são pintadas sobre a pedra. Apresenta o nome, data de nascimento, falecimento e epitáfio (Figura 26B).

Outro túmulo, do ano de 2007, com características muito próximas ao, de Pedro Alcântara Baião, descrito anteriormente. Trata-se de um jazigo confeccionado todo em mármore. Alguns objetos decorativos anexados ao suporte, como uma fotografia e dois jarros de flores estão presentes no túmulo, ainda possui uma cruz acrescida de um terço e bastante coroas de flores, e uma garrafa com água posta sobre túmulo. Este jazigo foi construído ligado a parede do cemitério, possuindo orientação para oeste. A lápide desse jazigo é retangular e resume apenas ao nome e data de nascimento e falecimento (Figura 26C).

Outro túmulo, pertencente a Laudelina Dias Damasceno, também do ano de 2007, está localizado no final do cemitério com orientação oeste. Apresenta revestimento em cerâmica na cor branca com ausência de cruz. A lápide está posta junto ao suporte, onde ficaria a cruz. A lápide desse jazigo é simples, não possuindo epitáfio, sendo confeccionada em mármore branco. As informações da identificação do inumado, as datas de nascimento e falecimento foram pintadas de preto para destacá-las (Figura 26D). 

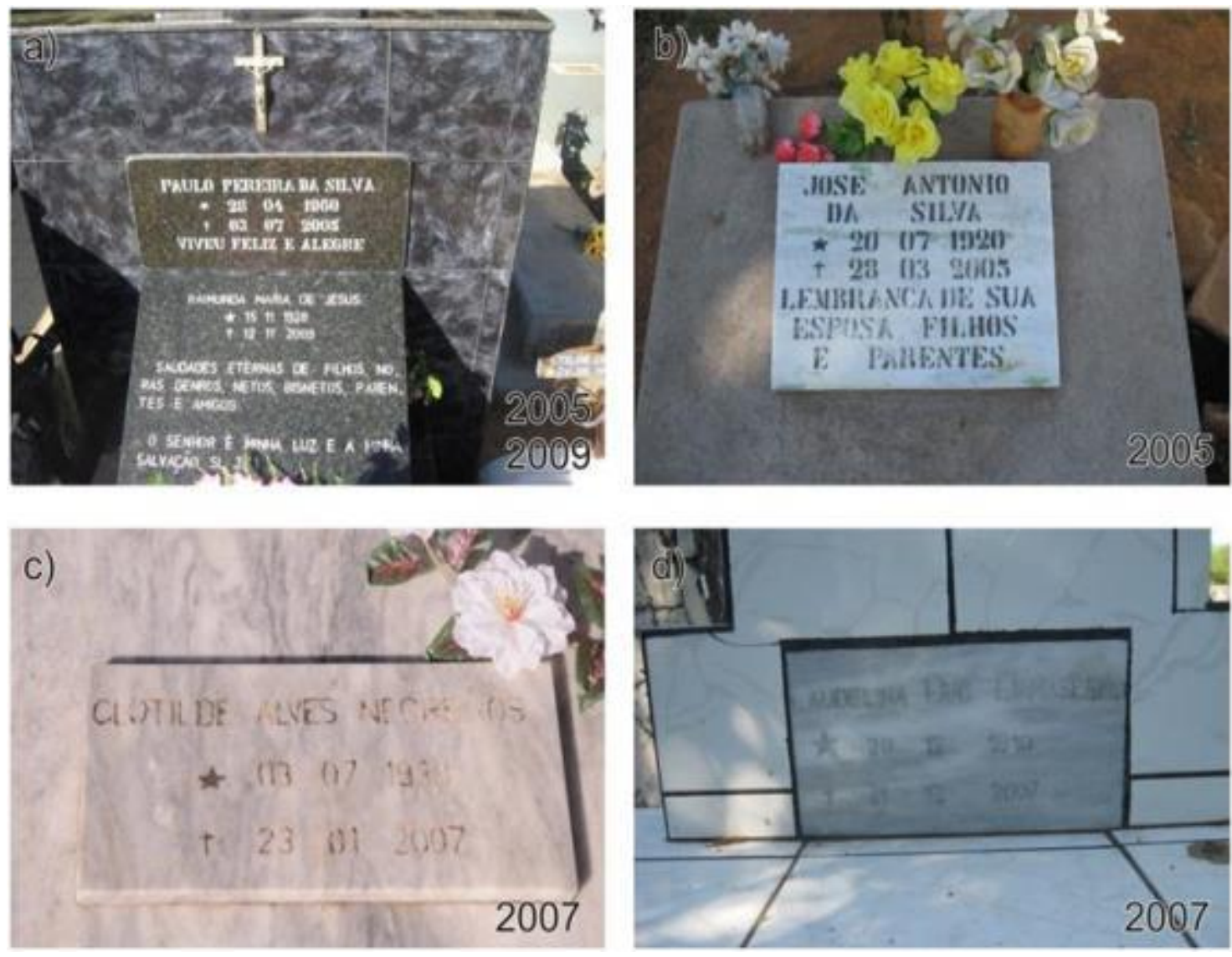

Figura 36: A, B, C, D. Lápides das décadas de 2000, dos anos de 2005, 2007 e 2009.

As observações e análises levantadas até o momento nesta pesquisa, tem a princípio mostrado que houve uma alteração nos valores arquitetônico em relação aos padrões construtivos do final século XIX ao início do XXI, percebem-se mudanças em relação a morfologia, o tamanho e uso do material construtivo dos jazigos.

É possível identificar uma brusca modificação na forma das lápides se tomarmos como base as assentadas antes da década de 1930 e as que apareceram na década de 1960. Todas deste primeiro momento apresentam pelo menos um símbolo iconográfico, enquanto que da década de 1960 em diante não existe nenhuma lápide ornamentada. Todas deste primeiro período estão na posição vertical, enquanto que todas as do segundo encontram-se em posição horizontal. É possível visualizar também o hiato cronológico entre os dois tipos de lápides como explicitado anteriormente. Os epitáfios são cada vez menos elaborados, constituídos atualmente de uma simplicidade e minimalismo.

Esta maior ostentação de símbolos, tamanho e detalhes nos jazigos do início do século XX pode estar relacionados à época em que a cidade estava em pleno desenvolvimento econômico devido à extração do látex, já que os períodos são coincidentes. No entanto, esta mudança pode ser também explicada por mudanças de como a sociedade se relaciona com a morte e a sua apresentação material. 
Uma característica comum, atualmente, em todos os túmulos é a utilização de velas, flores, garrafas com água, terços e orações que ganham um aspecto de verdadeiros rituais. Ressaltase que o ornamento mais encontrado sobre os túmulos foram os vasos com flores, seu uso é geralmente muito comum em sepultamentos sendo uma verdadeira demonstração viva de carinho. As flores ainda são vistas como representações do paraíso sendo uma forma de ter o descanso eterno mesmo como uma lembrança da vida terrena.

Vale ressaltar que os aspectos ornamentais encontrados nas lápides anteriores à década de 1930 permitem perceber a utilização de alguns ornamentos de forma continua (Tabela 3). A utilização de ramos como símbolo é praticamente contínua nas lápides durante o início do século XX. Enquanto a utilização da cruz envoltas em laços/ramos é encontrada nas duas lápides de 1927.

Tabela 3: Elementos iconográficos presentes nas lápides do cemitério Nossa Senhora de Lourdes.

\begin{tabular}{|l|l|l|}
\hline Lápide (Ano) & Símbolos Iconográficos & Características \\
\hline 1901 & Raixa e dois ramos de flores & Ramos \\
\hline 1915 & & Ramos e laço \\
\hline 1917 & & \\
\hline
\end{tabular}


Por fim o objetivo deste trabalho foi entender melhor como ocorreu o processo de implantação dos jazigos no Cemitério Nossa Senhora de Lourdes desde a utilização dos materiais construtivos acrescido dos elementos decorativos, a princípio nos mausoléus, onde se encontra uma maior quantidade de ambas as características. Nos túmulos, por serem em sua maioria da década de 1960 em diante, encontra-se a ausência de elementos decorativos estruturais. Atualmente parece haver uma tendência ao desaparecimento dos elementos decorativos e de epitáfios mais elaborados como os identificados nos mausoléus do início do século XX.

\section{Considerações Finais}

A pesquisa aqui apresentada teve como objeto de estudo os jazigos e lápides do Cemitério Nossa Senhora de Lourdes, datados desde o final do século XIX a início do século XXI. A cidade de São Raimundo Nonato passou por algumas mudanças socioeconômicas desde sua implantação. A agricultura de subsistência, criação do gado e extração da maniçoba foram algumas das atividades econômicas mais importantes desenvolvidas no município desde sua implantação.

No aspecto dos sepultamentos, enquanto que em outras regiões do país, ocorriam manifestações voltadas à preocupação com relação à proibição dos sepultamentos nas igrejas e a criação dos cemitérios em áreas afastadas do centro da cidade, em São Raimundo Nonato não se tem referência alguma. Provavelmente, como apontado anteriormente, as famílias que não pertenciam à elite local, não deviam sepultar seus mortos nem em cemitérios nem nas igrejas, mas sim no quintal ou pátio das casas durante este período.

O Cemitério Nossa Senhora de Lourdes teve seu interior analisado sendo identificado o conjunto de jazigos que foram distribuídos em mausoléus, túmulos, covas rasas, lápides, epitáfios, ornamentos e inscrições fúnebres apresentadas como sendo uma representação da relação do homem com a morte. Nesse espaço buscou-se uma reprodução dos elementos sagrados no interior dos templos procurando uma proximidade com as formas dos sepultamentos antigos. Na pesquisa foram elaborados alguns parâmetros para melhor identificar essas relações.

Pela observação das informações contidas nos jazigos e lápides, pode-se inferir que o cemitério Nossa Senhora de Lourdes possui sepultamentos de pessoas de pequenos núcleos familiares. Os descendentes destas famílias procuram sempre limpar os espaços entre os jazigos e conservar o cemitério da melhor maneira possível. No entanto, a gestão do poder público municipal deixa algo a desejar, já que não existe uma organização formal dos espaços nem uma política de revitalização da área.

A partir desta pesquisa foi possível ter evidências de que o cemitério Nossa Senhora de Lourdes esteve parado nas décadas de 1930 e 1940, pois não foi evidenciado nenhum jazigo pertencente a essas décadas. Como a população local reforça que houve um período que o cemitério foi desativado, aponta-se para que isto tenha acontecido nestas décadas, já que, 
como explicitado anteriormente, não existe nenhuma documentação sobre a construção ou atividades desenvolvidas nos dois cemitérios da cidade.

Este período de hiato, entre o final da década de 1920 e início da década de 1950, representa uma quebra bastante significativa nos padrões construtivos dos jazigos e na forma de apresentação das lápides.

Foi possível verificar três momentos distintos na morfologia dos jazigos tomando como referência o revestimento utilizado nos mesmos. Entre os anos de 1880 a 1920, há a utilização exclusiva do cimento como revestimento; nas décadas de 1950 a 1970 o cimento é substituído pelos azulejos como forma de revestimento; a partir da década de 1980 vários materiais construtivos passam a serem utilizados como revestimento dos jazigos.

Nas lápides também é possível identificar uma brusca modificação na sua morfologia antes e depois do hiato entre o final da década de 1920 e início da década de 1950. Todas deste primeiro momento apresentam pelo menos um símbolo iconográfico, enquanto que da década de 1960 em diante não existe nenhuma lápide ornamentada. Todas deste primeiro período estão na posição vertical, enquanto que todas as do segundo encontram-se em posição horizontal. Os epitáfios mais recentes são cada vez menos elaborados, constituídos atualmente de uma simplicidade e minimalismo.

Essa análise detalhada contribuiu para entende-se melhor como a sociedade de São Raimundo Nonato conduzia seus rituais com relação à morte e até onde vai a preocupação em sepultar em estruturas significantes de beleza e respeito ao morto, sejam eles monumentos, simples túmulos ou covas-rasas.

\section{Referências}

BARRETO. P. T. O Piauí e a sua Arquitetura. Revista SPHAN, n.02, 1940.

CISNEIROS. D. Práticas funerárias na Pré-história do Nordeste do Brasil. Recife-Pe: UFPE, 2003 (Dissertação de mestrado).

COSTA, F. M. M. da. A Morte e o Morrer em Juiz de Fora:

Transformações nos costumes fúnebres, 1851-1890. Juiz de Fora: UFF, 2007 (Dissertação de Mestrado).

DIAS, C. M. M. Que história é essa?Teresina: EDUFPI, 2005.

DIAS, W. P. São Raimundo Nonato de Distrito - Freguesia a Vila. 1ạ edição. Teresina, 2001.

GUERRA, A. T.; GUERRA, A. J. T. Novo Dicionário Geológico-Geomorfológico. 3a Ed. Rio de Janeiro: Bertrand Brasil, 2003.

IBGE, Instituto Brasileiro de Geografia e Estatística. Planilha de Contagem da População IBGE. São Raimundo Nonato, 2007.

IPHAN. São Raimundo Nonato: Memória e Patrimônio - Serra da Capivara. Ana Stela N. de Oliveira, Cristiane de A. Buco. Elaine Ignácio (org.) Teresina - PI. Editora: IPHAN, 2001.40p. 
FLORES, A. P. M. Descanse em Paz: Testamentos e Cemitério

Extramuros na Santa Maria de 1850 a 1900. Porto Alegre: PUCRS, 2006 (Dissertação de Mestrado).

FUNARI, P. P. Arqueologia. São Paulo: Contexto, 2003.

LIMA, T. A. De morcegos e caveiras a cruzes e livros: a representação da morte nos cemitérios cariocas do século XIX(estudo de identidade e mobilidade sociais). Anais do Museu Paulista. São Paulo. N. Ser. V. 2p. 87-150. Jan./Dez. 1994.

OLIVEIRA, A. S. de N. Catingueiros da Borracha: Vida de Maniçobeiro no Sudeste do Piauí - 1900 - 1960. Recife: UFPE, 2001 (Dissertação de Mestrado).

ORSER, C. E. Introducción a la Arqueología Histórica.Buenos Aires:Asociación Amigos del Instituto Nacional de Antropología,2000.

PENA, B.; NEIVA, A. Viagem Científica ao Norte da Bahia, Sudoeste de Pernambuco, Sul do Piauí e de Norte a Sul de Goiás. In: Memórias do Instituto Oswaldo Cruz. Rio de Janeiro, 1916.

PAGoto, A. A. Do Âmbito Sagrado da Igreja ao Cemitério Público: Transformações Fúnebres em São Paulo (1850-1860). São Paulo: Arquivo do Estado, 2004 (Coleção Teses e Monografias, 7).

PESSIS, A-M. Imagens da Pré-História. Parque Nacional Serra da Capivara. Fumdham/Petrobras, 2003.

RIBEIRO, M. S. Arqueologia das práticas mortuárias: Uma abordagem historiográfica. São Paulo: Alameda, 2007.194p.

REIS, J. J. A Morte é uma Festa: Ritos fúnebres e revolta popular no Brasil do século XIX. São Paulo: Companhia das Letras, 1991.357p.

REIS, J. J. O cotidiano da morte no Brasil Oitocentista. In: NOVAIS, F. A. (Coord.)

História da Vida Privada no Brasil: Império. São Paulo: Companhia das Letras, 1997. v.2. p.95-141.

SANTOS, M. F. dos. Memória coletiva e teoria social. São Paulo: Anna Blume, 2003.

SILVA FILHO, O. P. da. Carnaúba, Pedra e Barro na Capitania de São José do Piauhy. Belo Horizonte. 3 v.Il.:Ed.do Autor, 2007.

SILVA, S. F. S. M. da. Arqueologia das Práticas Mortuárias em Sítios Pré-Históricos do Litoral do Estado de São Paulo. São Paulo: MAE-USP, 2005 (Tese de Doutorado).

WILLIAMS, R. Palavras-Chave: um vocabulário de cultura e sociedade. São Paulo: Boitempo, 2007. 